\title{
Darağacında Bir Serdengeçti Davası: Medeniyet ve Mekân Bağlamında Ayasofya
}

DOI: $10.26466 /$ opus. 850459

Hatice Budak*

* Dr. Öğr. Üyesi, KTO Karatay Üniversitesi, Sosyal ve Beşeri Bilimler Fakültesi, Konya/Türkiye E-Posta: hatice.budak@karatay.edu.tr

ORCID: $\underline{0000-0002-9815-9997}$

Öz

Mekân, toplumların yapısina, üyelerinin karakterlerine ve tarihsel süreçte edinilen birikimlerini temsil eden medeniyet anlayışlarına etki eden faktörlerden biridir. Bir toplumun medeniyet anlayışı da mekânların oluşmasında, mekânların birincil fonksiyonlarının ötesinde müstesna anlamlar kazanmasında etkilidir. Mekânın doğasında medeniyet ilişkilerini ve mücadelelerini barındırması özellikle bazı tarihi mekânların dönemsel olarak iktidar müdahalelerine açık olmasına neden olmuştur. Bu mekânlardan en bariz olanı Ayasofya'dır. Bu çalışmada Türk düşün ve edebiyat dünyasının önemli isimlerinden biri olan Osman Yüksel Serdengeçti ve onun Ayasofya başlıklı yazısl, medeniyet ve mekân ilişkisi açısından ele alınmıştır. Bu çalışmanın amacı O. Y. Serdengeçti'nin "Ayasofya" adlı yazısının analizi doğrultusunda Ayasofya'nın her iki medeniyet içinde dini, siyasi, tarihsel, kültürel anlamlara sahip ve bu anlamlar sebebiyle mücadele alanı olduğunu medeniyet ve mekân ilişkisi içinde göstermektir. Çalışmanın yöntemi, Dey tarafından geliştirilen ve "nitel analiz" olarak adlandırılan modele dayanmaktadır. Çalışma sonuçlarına göre Serdengeçti'nin yazısında Ayasofya'yı mekân-insan ve medeniyet ilişkisi noktasında ele aldı̆̆ını, Ayasofya'nın bir Bizans müzesi olacak şekilde yapılandırılmasının ardından cami olarak açılması ile mekânda tezahür eden Bizans/Batı Hristiyan medeniyetine ait izleri ve anlamlarn ters düz ederek mekâna İslam- Türk medeniyeti kimliğini yeniden kazandırmak istediğini, Ayasofya'yı bir medeniyetin ve toplumun diriliş mekânı olarak değerlendirdiğgini ifade edebiliriz.

Anahtar Kelimeler: Medeniyet, mekân, medeniyet-mekân ilişkisi, Ayasofya, Osman Yüksel Serdengeçti. 


\title{
A Serdengeçti Case on A Scaffold: Hagia Sophia Within the Context of Civilization and Place
}

*

\begin{abstract}
Place is one of the factors that effects the structure of the societies, characteristics of their members and the understandings of civilization, which represent the accumulation within the historical process. The view of civilization of a society has been effective on the generation of the places and obtaining unique meanings of places beyond their initial function. The situation that the place harbors civilizational relationships and struggles causes some of the historical places to be open to interventions by power cyclically. The most obvious one among these places is Hagia Sophia. In this study, Osman Yüksel Serdengeçti, who is one of the most important figures among Turkish world of thought and literature, and his article titled "Hagia Sophia" have been discussed in terms of the relationship between civilization and place. The purpose of the study is to show within the relationship between civilization and place that Hagia Sophia keeps religious, historical and cultural meanings and becomes a field of struggle for both civilizations due to these meanings in line with the analysis of O. Y. Serdengeçti's article titled "Hagia Sophia". The method of the study is based on the model developed by Dey (1993) and identified as "qualitative analysis". According to findings of the study, we can assert that Serdengeçti deals with Hagia Sophia in his article on the basis of relationship between place-human and civilization, due to opening Hagia Sophia as a mosque after being structured as a Byzantine museum, traces and meanings belong and applied to Byzantine/Western Christian civilization have been reversed, so the place was given the identity of Islamic-Turkish civilization, and Hagia Sophia is evaluated as a resurrection place of a civilization and society.
\end{abstract}

Keywords: Civilization, place, civilization-place relationship, Hagia Sophia, Osman Yüksel Serdengeçti. 


\section{Giriş}

Volkan gibi lav atmış, ne susmuş ne sönmüşüm. Ben bu îmân uğruna çılgınlara dönmü̈süm. ${ }^{1}$

Osman Yüksel Serdengeçti

İnsana varlık alanında kendini gerçekleştirme imkânı sunan unsurlardan biri mekândır. İnsan ve mekân ilişkisi, süje ve objenin yer değiştirdiği ve bu döngüsel değişimde birbirlerini biçimlendirdikleri bir ilişki biçimidir. Mekânın ürettiği insan, insanın ürettiği mekân ve insanın ürettiği mekânın insanı yeniden üretmesi karşılıklı etkileşimin tezahürüdür. Medeniyette bir yönüyle mekân ve insan ilişkisinden doğan, mekânın sembolik anlamları ile bağ kuran ve bu bağ ile farklılaşan, özgün bir hüviyet kazanan birikimdir.

Mekân, her zaman medeniyetlerin gücünü ve dünya görüşünü yans1tan belirgin bir semboldür. Bu nedenle mekân, kendi mimari ve işlevsel yapısının dışına çıkartılarak tarihsel bağlamda medeniyetlerin farklılıklarını göstermede ve birbirleri ile mücadelelerinde kullanılan etkili bir araç olmuştur.

Her devletin ve her şehrin kutsal bir mekânı vardır. İstanbul'unki bir Bizans şehri iken de fetih ile Osmanlı şehri olduktan sonrada Ayasofya olmuştur. Ayasofya Batı/Hristiyan medeniyeti ve Doğu/İslam medeniyeti için ilahi hikmeti, mukaddesatı, dünya görüşünü ve milletin tarihini, kültürünü temsil eden sembol bir mekândır.

Doğu Roma İmparatorluğu tarafından yapılan ve yaklaşık bin yıl kadar Hristiyanlığın merkezi olan Ayasofya, İstanbul'un Türkler tarafından fethedilmesi ile fetih/kılıç hakkı geleneğine uygun olarak camiye dönüştürülmüştür. Osmanlı İmparatorluğu'nun mali krizler yaşadığ 1 dönemlerde dâhil olmak üzere ihmal edilmeyen yapı Türk-İslam medeniyetinin mimari üslupları tatbik edilerek zamanla tam bir Osmanlı külliyesi haline getirilmiştir.

Medeniyet ve mekân arasındaki ilişkinin güçlü örneklerinden biri olan Ayasofya, geçmişten günümüze kadar çeşitli sosyal bilimlerin inceleme nesnesi olmakla birlikte Türk edebiyatında da Doğu/İslam medeni-

\footnotetext{
${ }^{1}$ Osman Yüksel Serdengeçti, Bir Kahraman Bekliyoruz (1942/Ankara) adlı şïrinden alınmıştır.
} 
yetinin ve Türk milletinin ruhunu yansitan müstesna bir mekân olarak ele alınmıştır.

$\mathrm{Bu}$ çalışmanın çıkış noktasını seksen altı yıl müze olarak faaliyet gösteren Ayasofya'nın 24 Temmuz 2020 tarihinde kılınan Cuma namazı ile yeniden cami hüviyetini kazanması, bir neslin ömre bedel davalarının ışığından gayrı ele alınmamalı düşüncesi tayin etmiş ve çalışmayı Osman Yüksel Serdengeçti ile buluşturmuştur. Çalışmada Osman Yüksel'in Serdengeçti dergisinin Ağustos-1952 tarih ve 17. sayısında yayınlanan, şiirsel bir üslupla kaleme alınan "Ayasofya" başlıklı yazısı odak metin olarak seçilmiştir. Çalışmada O. Y. Serdengeçti ve yazısının odak metin olarak seçilmesinde yazının yayınlanmasından üç ay sonra metnin içeriği nedeniyle Serdengeçti hakkında idam talebiyle dava açılmış olması da etkili olmuştur.

Çalışmanın amacı O. Y. Serdengeçti'nin "Ayasofya" adlı yazısının analizi doğrultusunda Ayasofya'nın her iki medeniyet içinde dini, siyasi, tarihsel, kültürel anlamlara sahip ve bu anlamlar sebebiyle mücadele alanı olduğunu medeniyet ve mekân ilişkisi içinde göstermektir.

Çalışmanın yöntemi, Dey (1993) tarafından geliştirilen ve "nitel analiz" olarak adlandırılan betimleme, sınıflandırma ve ilişkilendirme olmak üzere üç bölümden oluşan modele dayanmaktadır. Nitel analizin ilk basamağını oluşturan betimleme kişi, nesne ve olaylara ilişkin temel özelliklerin yazılı olarak ifade edilmesi olarak tanımlanmaktadır. Verilerin kapsamlı betimlemesinin ardından, veri seti içerisinde örtük olarak duran temalar, ortaya çıkartılmakta ve bu temalar birbirleri ile ilişkilendirilerek inceleme konusu olan sosyal gerçeklik açılanmaya çalışılmaktadır (Özdemir, 2010, s.330-331).

Çalışmanın ilk bölümünde mekân ve medeniyet kavramlarının tanımı, Ayasofya'nın tarihçesi, Doğu/İslam ve Batı/Hristiyan medeniyetlerinde Ayasofya'nın sembolik anlamları ve önemi konuları ele alınmıştır. Çalışmanın ikinci bölümünde ise Osman Yüksel Serdengeçti'nin medeniyet ve mekân anlayışından hareketle Ayasofya yazısı analiz edilerek Ayasofya'nın bir medeniyet mekânı olarak sembolik anlamları tarihsel vakıalarla ilişkilendirilerek ortaya konulmaya çalışılmıştır. Çalışma, metnin analizinden elde edilen verilerin bütünleştirildiği sonuç kısmı ile tamamlanmıştır. 


\section{Mekân ve Medeniyet Kavramı}

TDK (2009, s.1363) sözlüğünde yer, bulunulan yer, ev, yurt, uzay anlamları verilen mekân kavramını sadece üzerinde yaşanılan somut bir alan olarak tanımlamak yetersizdir. Mekân canlıdır; toplumsal olarak üretilir ve kendisi de anlam- değer üretir (Salman, 2015, s.221).

Mekân, bireylerin organik olarak yaşama anlam verme, kim oldukları veya kim olacaklarına dair bir kimlik oluşturma süreçlerinin etkin bir parçasıdır (Thorns, 2, s.9). Bu tanımla mekân toplumun bir nevi kimliğidir. Mekânın toplumsal kimlik anlamı, çeşitli sembolik figürler kullanılarak taçlandırılıp pekiştirilir. Örneğin; hilal İslam'ın; haç ise Hristiyanlığın mekân üzerine vurduğu mühürlerdir (Oktay, 2012, s.30).

Mekânın süreklilik özelliği, "zihinsel olanla kültürel olanı, toplumsal olanla tarihseli birbirine bağlar." (Lefebvre, 2014, s. 25). Süreklilik farklı zaman birimlerinin kesintisizliğini mekân üzerinden anlatma çabasıdır. Bu açıdan mekânda süreklilik, mekânı şekillendiren ana etmenlerin varlığını ve canlılı̆̆ını koruması, buna göre gerçekleşen değişimlerin kesintisizliğini, bunların karşıtlık içinde olsalar bile bir tenakuza sebebiyet vermeyişini, aslî ya da hadis olan her şeyin bir bütünün parçası olarak var olmasinı ve devam etmesini ifade eder (Enser, 2018, s.268-269)

Mekân, her şeyden önce bir dünya görüşüne, bir inanca, orayı işgal eden insanın ruhî/psişik tarafına göre şekillenmiş bir alandır. Bu sebepledir ki, süreklilik fikri, tarihle ilgisinin yanında daha ziyade medeniyet kavramıla ilgilidir; zira süreklilik, insan ömrünü aşan, daha uzun süreli bir teşekkülü, bir yapıyı öngörür (Enser, 2018, s.269).

Kelime anlamı "şehirleşmek, şehir hayatını benimsemek" (Kazıcı, 2009, s.17) olan medeniyet kavramının terimsel tanımlamasını yapmak bir hayli zordur. Bu zorluğa rağmen genellikle kolektif değerler bütünü olarak medeniyetin, insanı diğer varlıklardan ayıran, özünde rasyonel olan ve klymet ifade eden bir durum yahut seviye olarak kabul edildiğini belirten Kalın, kendi özgün tanımını ise şu şekilde vermektedir. Medeniyet sosyal, ekonomik ve siyasî bir düzen fikrine dayanmakla birlikte aslen "bir dünya görüşünün zaman ve mekân boyutunda tezahür ve tecessüm etmesi"dir (Kalın, 2010, s.2-21-22).

“Medeniyet, insanoğlunun, esas gayesini gerçekleştirme çalışmalarından, ona varma arayışlarından, onu bulmuşsa kaybetmeme çabasın- 
dan, o yöndeki duygularını ve düşüncelerini ifade etme isteğinden doğan teori ve pratiğinin, tasarım ve eserlerinin, reel ve potansiyel güçlerinin tümü" demektir (Karakoç, 2005, s.9).

Medeniyet, hayatımızın her safhasında, duygularımız, düşüncelerimiz ve davranışlarımızla karşılaştığımız bütüncül bir olaydır. Yani, her an, her hareketimiz medeniyetle ölçülür, medeniyetle tartılır ve medeniyetle değerlendirilir (Karakoç, 2012, s.134).

Braudel ise medeniyet tanımında köken olarak din faktörünü de dikkate alır. Ona göre medeniyetler hemen her zaman dine dayanmakta, ezelden beri dinselliği içinde yaşamakta, kendilerine özgü psikolojilerinin en güçlü güdülerini dinden sağlamaktadır (Braudel, 2017, s.55).

Bir medeniyetin sadece kendi kaynakları ile var olduğunu söylemek oldukça zordur. Bir medeniyetin ortaya çıkışında başka bir medeniyetin kaynaklığı ve etkisi söz konusudur. Medeniyetler arasındaki etkileşimin varlığını dikkate almaktan tüm uygarlıkların bir bakıma birbirlerini aynı istikamette takip ettikleri ve aynı niteliklere sahip oldukları sonucu ç1kartılmamalıdır. Her medeniyetin kendine özel esas niteliklerinin olduğu da bilinmelidir (Özkul, 2004, s.168).

Her bir medeniyet kendine kimlik kazandıran ve onu diğerlerinden farklı kılan bir ruha sahiptir. Medeniyetin ruhu, o medeniyetin insanlarının arzuları, idealleri ve amaçlarından hasıl olmaktadır (Niyazi, 2007, s.170).

Medeniyetleri kategorize etme ve adlandırma çalışması coğrafi sınırlar ve dünya görüşleri gibi birtakım kriterler üzerinden yapılmaya çalışılsa da her zaman eleştiriye açık sorunlu bir çabadır. Bu zorlukla birlikte medeniyetler tarihi alanında Doğu medeniyeti ve Batı medeniyeti olmak üzere iki ana çerçeve ile karşılaşılmaktadır.

Medeniyet kavramını din merkezli açıklayan görüşler dikkate alındığında Batı medeniyeti Hristiyanlık ve Yahudilik, Doğu medeniyeti ise genellikle İslamiyet ile ilişkilendirilmiştir. Günümüzdeki kullanım anlamı itibariyle Batı medeniyeti, aklın rehberliğinde bilimsel bilgi ve teknolojik üstünlüğü, dünya görüşü ile tutum ve davranışlarda gelişmişliği kendine mahsus görme (Kalın, 2010, s.6) biçimi olarak algilansa da aslen Batı medeniyetinin özü de dindir. 
Braudel'e göre de Batı medeniyetinin gelişme eğilimi akılcılık yönünde olsa bile Hristiyanlık, Batı toplumunun hayatının esaslı gerçeklerinden biridir (Braudel, 2017, s.54).

Doğu medeniyetinin içinde değerlendirilen ve adeta Doğu medeniyeti ile özdeşleştirilen İslam medeniyeti, Arap, Fars, Türk, Hint toplumları ile Abbasi, Endülüs, Selçuklu, Osmanlı devletlerinin şekillendirdiği medeniyetlerin ortak teşekkülü olarak değerlendirilebilir.

İslam medeniyetinin temelleri Kuran-1 Kerim ve Sünnete dayanmaktadır. İslam medeniyeti, vahiy merkezli olup, akıl ve duygunun uyumlu bir sentezi olarak ortaya çıkmıştır. Din medeniyetin bir unsuru değil, medeniyetin yönlendiricisidir. İslam medeniyetinin ana gayesi, insanın inanç, can, mal, nesil ve akıl gibi temel değerlerini koruma altına alma suretiyle tüm insanların haklarını korumaktır (Şemşek, 2020, s.283-284).

Bu çalışmada Batı medeniyeti kavramlaştırmasında dini dayanak olarak Hristiyanlık, Doğu medeniyeti kavramlaştırmasında ise İslamiyet esas alınmıştır.

\section{Ayasofya'nın Tarihçesi}

Doğu Roma İmparatorluğu'nda ilk yapıldığında Ayasofya'ya Büyük Kilise anlamına gelen Megale Ekklesia adı verilmiş, beşinci yüzyıldan sonra ise Ayasofya adını almıştır. Ayasofya, kelimesinin anlamı çeşitli kaynaklarda "kutsal bilgelik, Tanrı'nın hikmeti, İlahi hikmet, Allah'ın evi, Allah'ın sevgisine mazhar olan evliyaların toplandığı yer" olarak verilmiştir (Aslan, 2009, s. 15-16).

Ayasofya'nın ilk olarak kim tarafından ve ne zaman inşa edildiği hakkında muhtelif görüşler bulunmaktadır. Ayasofya hakkında yazılan literatüre dayanarak tarihsel süreci Roma İmparatoru I. Konstantinos'un(324-337) tahta geçtikten sonra yasak olan Hristiyanlık dinini resmi din olarak kabul etmesi ve bu gelişmeden sonra imparatorluğunun farklı bölgelerinde kiliselerin yapılmaya başlanması ile başlatmak mümkündür. I. Konstantinos'un kendi iktidarının ve Hristiyanlığın zaferini temsil etmek niyetiyle görkemli bir kilise yapmaya karar verdiği, bu niyet üzere Ayasofya'nın inşasına başlandığı söylenmektedir. Ancak I. Ayasofya, I. Konstantinos tarafından değil oğlu II. Konstantinos zama- 
nında babasının vasiyeti gereğince bazilika şeklinde yaptırılıp 15 Şubat 360 yılında tamamlanmıştır (Mansel, 1979, s.48; Eyice, 1993, s.44).

İmparator Arkadios'un aralarındaki anlaşmazlıklar sebebiyle Konstantinopolis Patriği İoannes Khrysostomos'u sürgün etmesi sonucunda 20 Haziran 404'te halkın çıkardığı isyandaki yangınlarda önemli bir kısmı yanan (Eyice, 1984: 6), İstanbul'daki depremde de büyük hasar gören (Akgündüz vd, 1994, s. 38) Ayasofya, II. Theodosios (408-450) zamaninda yeniden onarılıp 10 Ekim 415 tarihinde ibadete açllmıştır (Akgündüz vd., 2005, s.85) .

13-14 Ocak 532 yılındaki Nika Ayaklanmasında II. Ayasofya kilisesi bir kez daha yanmış (Eyice, 1984, s.6) ayaklanmayı bastıran I. Iustinianus 23 Şubat 532'de kilisenin yapımını başlatmış, 26 Aralık 537 yılında açılış merasimi yapılmış (Akgündüz vd., 1994, s.49-63) ve birtakım onarımlarla 562 yılında tamamlanan III. Ayasofya kilisesi günümüze kadar ulaşmıştir.

Hz. Peygamber Efendimizin, "Konstantiniyye (İstanbul) muhakkak fethedilecektir. Onu fetheden emîr ne güzel emirdir. Onu fetheden ordu ne güzel ordudur." hadis-i şerifindeki övgüye mazhar olma arzusu Müslümanların İstanbul'u fethetme çabalarını erken bir tarihte başlamasının temel nedenlerinden biridir. Ayrıca İstanbul ve İstanbul'u temsil eden şehrin en büyük mabedi olan Ayasofya Bizans İmparatorluğu'nun ve Hristiyanlık dünyasının merkezi sembolü olması da İslam'1 hak kılmak isteyen Müslümanların fetih arzularını beslemiştir ( Aslan, 2009, s.55).

İstanbul'un fetih hareketi Hicrî 52, miladî 672 yılında Hz. Muhammed'in mihmandarı olan Ebu Eyyub el-Ensarî ile başlayacaktır. Diğer taraftan bir kısım kaynaklarda Emevîlerle Abbasîlerin H.34/655H.169/785 tarihleri arasında İstanbul'a beş sefer düzenledikleri belirtilmektedir. İstanbul'un fethi Fatih Sultan Mehmet'in Bizans'a giriştiği son hamle ile neticelenecektir (Öztürk, 2003, s.133).

29 Mayıs 1453'te İstanbul fethedildikten sonra "fetih-kılıç hakk1" denilen gelenek takip edilerek Fatih'in emriyle Ayasofya camiye çevrilecek ve ilk Cuma namazı burada kılınacaktır. Fatih Sultan Mehmet tarafından "Ayasofya-i Kebîr Cami-i" adı verilen yapı Fatih'in kendi adına olan vakfiyesine mülk eylenecek ve fetihten hemen sonra onarım çalışmaları başlayacaktır. Tarihsel süreç içinde eklenen minareleri, mihrabı, minberi, 
medrese, imareti vd. ile Ayasofya, Osmanlı ve İslam medeniyetinin önemli mabetlerinden biri haline gelmiştir.

İstanbul'un fethi ve Ayasofya'nın akıbeti Batı medeniyeti için her daim kanayan bir yara olarak kalmışsa da Osmanlı'nın kudretli zamanlarında belirgin bir sorun yaşanmamıştır. Ancak I. Dünya savaşının ardından imzalanan Mondros Mütarekesi ile İstanbul'un fiili işgali sonrasında Ayasofya'nın kilise yapılması için Batılıların ve Rumların talepleri ve faaliyetleri başlamış ve ardı kesilmemiştir ( Eyice, 1986, s.19).

Osmanlı topraklarının işgal sürecinde galip devletlerden güç alan Rumlar gerek İstanbul'da gerekse Anadolu'da yerli halka karşı fütursuzca davranışlarda bulunmuş, Yunan askerleri ise caddelerde "Ayasofya'yı alacağız, Türkleri kovacağız" diye şarkılar söylemişlerdir. Yaşanılan vahim olaylara rağmen İstanbul'un işgal yıllarında ve Anadolu'daki milli mücadele zarfında Ayasofya ezanların sürekli okunduğu Türk ve Müslüman cami olarak kalmıştır (Akçay, 1967, s.6).

Ayasofya'nın müzeye dönüştürülmesi Cumhuriyet dönemine tekabül etse de tarihsel arka plana bakıldığında I. Dünya savaşı sonrasında yaşanılan işgal yıllarında, Paris Konferansında, Sevr Antlaşmasında ve Lozan Konferansında Ayasofya'nın kilise olması şayet kilise olamayacaksa müze olması sürekli dile getirilmiştir.

Ayasofya'nın müze yapılması ile ilgili süreç Atatürk'ün onayı alınan 07.06.1931 tarih ve 11195 sayılı Bakanlar Kurulu kararı ile bir uzman nezaretinde çalışması şartıyla Whittemore ve ekibine izin verilmesi ile başlamıştır. Ayasofya'nın mozaiklerinin açığa çıkartılması görevinin yurtdışından getirilen bir uzman ekibe verilmesi ile olaya uluslararası bir boyut kazandırılmış (Kleinbauer vd., 2004, s.121) ayrıca yüzyıllardır İslam'ın temsili olan caminin müzeye çevrilmesine yapılacak itirazlar önlenmek istenmiştir.

Whittemore, 1931 yılı itibariyle Ayasofya'da başlayan çalışmalarını Amerika'daki Bizantin Enstitüsü'nün uzman ve maddi destekleri ile 1938 yılına kadar sürdürmüştür.

Ayasofya' da Bizans dönemine ait izlerin çıkartılmasına izin veren çalışmaların ardından müze olarak yapılandırılabilmesi içinde bir dizi hukuki adımlar atılması gerekilmiştir. Bu adımlar arasında Ayasofya'nın akıbetini belirleyecek olan 25 Aralık 1932 tarihli "Cami ve Mescitlerin Sınıflandırılması Hakkında Nizamname"nin çıkarılması olmuştur. Ni- 
zamnamede yer alan maddeler gereğince Ayasofya Cami, halkın ibadet ihtiyacını karşılayacak camilerin (Süleymaniye camii vd.) olduğu bir konumda bulunması nedeniyle ibadete kapatılacaktır (İkinci, 2014, s.116117).

24 Kasım 1934 tarih ve 7/1589 Bakanlar Kurulu kararı ile Ayasofya caminin müzeye çevrilmesi hem İslam dünyasında hem de ülke içinde büyük teessür yaratmıştır. Ancak ülke içinde Ayasofya'nın müzeye çevrilmesine yönelik aydınlar tarafından dile getirilen tepkilerin vakıanın yaşandığı tarihlerde yeter düzeyde olmadığı tepkilerin 1950'ler sonrasında sesli olarak verildiği görülmektedir.

Ayasofya'nın Türk halkı için cami olarak tartışılmaz kıymetine rağmen müzeye çevrilmesi karşısındaki bu derin sessizlik İbrahim Hakkı Konyalı tarafından "Halk, caminin kapatılması konusunda büyük bir üzüntü duymuştu ve duruma isyan hali içindeydi. Ancak mahkemeler vardı. Kimse sesini çıkaramadı, çıkaramazdı da..." (Yakın Tarih Ansiklopedisi, 1989, s.15) şeklinde yorumlanmıştır.

1950'den sonra CHP'nin muhalefet partisine dönüşmesi, iktidara gelen Adalet Partisi'nin muhafazakâr boyutu ve sosyo-siyasal düzlemde demokratikleşme adımlarının yarattı̆̆ı kısmi özgürlük ortamında Ayasofya'nın yeniden ibadete açılmasına dair halk ve bazı aydınlar taleplerini ifade etmeye başlamışlardır.

Ayasofya'nın camiye dönüştürülmesi noktasında ilk adım Kartal Yunus İstasyon makasçısı Halit Deli Yumruk'un Başbakan Adnan Menderes'e gönderdiği mektupla ve ikinci adım ise 1950'li yıllarda Türk Milliyetçileri Derneğinin talebi ile atılmıştır. Ayasofya Müzesinin cami olarak açılması için ilk kanun tasarısı Vakıflar Genel Müdürlüğü’nün teşebbüsü ile hazırlanmıştır. Bu kanun tasarısının bir sonucu olarak Ayasofya'nın hünkâr mahfili 8 Ağustos 1980 tarihinde ibadete açılmış, 12 Eylül 1980 askeri darbe müdahalesinden sonra kapatılmış ve 10 Şubat 1991'de Ayasofya'nın hünkâr mahfili yeniden ibadete açılmıştır (Akan, 2008, s.56-61).

Sürekli Vakıflar Tarihi Eserlere ve Çevreye Hizmet Derneği tarafından Ayasofya'nın camiden müzeye dönüştürülmesine yönelik 1934 tarihli Bakanlar Kurulu kararının iptali ve yürürlüğün durdurulması" talebi ile 2005 ve 2016 yıllarında Danıştay’a açılan davalar sonuçsuz kalmıştır. Bu olumsuz gelişmelerle birlikte 1991'den beri ziyaretçilerin namaz kılabildikleri Hünkâr Kasr-1'na Ekim 2016 yılında Diyanet İşleri 
Başkanlığı tarafından ilk kez asaleten imam atanmıştır. Yıllar sonra Sürekli Vakıflar Tarihi Eserlere ve Çevreye Hizmet Derneği' nin açtığı dava kazanılmıştır. 2 Temmuz 2020 tarihinde gerçekleştirilen duruşmanın ardından Danıştay 10. Dairesi 10 Temmuz 2020 tarihinde, 24 Kasım 1934 yılında Bakanlar Kurulu'nun Ayasofya'yı müzeye dönüştürme kararını “Ayasofya'nın Fatih Sultan Mehmet Han Vakfının mülkiyetinde olduğu, tapu belgesinde cami vasfı ile tescilli bulunduğu, cami vasfı dışında kullanımın ve bir amaca özgülenmesinin hukuken mümkün olmadığı" gerekçesiyle (https://www.memurlar.net/haber/915648/danistay-in-ayasofya-kararigerekcesi-aciklandi.html).

Cumhurbaşkanı Recep Tayyip Erdoğan, Danıştay'ın Ayasofya hakkında kararını açıkladığı gün olan 10 Temmuz'da saat 20.53'te Millete Sesleniş konuşmasında kararı değerlendirmiştir. Cumhurbaşkanı Erdoğan konuşmasında, "Ayasofya, 86 yıl aradan sonra yeniden, Fatih Sultan Mehmet Han'in vakfiyesinde belirttiği şekilde cami olarak hizmet vermeye başlayabilecektir. Ayasofya'nın hangi amaçla kullanılacağı konusu, Türkiye'nin egemenlik haklarıyla ilgilidir. Bu konuda, görüş belirtmenin ötesindeki her türlü tavrı ve ifadeyi, bağımsızlı̆̆ımızın ihlali olarak kabul ederiz" (https://www.akparti.org.tr/media/324424/agustos_2020.pdf) ifadelerine yer vermiştir.

Danıştay 10. Dairesi'nin kararını açıklamasının ardından başlayan süreç ile Diyanet İşleri Başkanlığına devredilen Ayasofya, 24 Temmuz 2020 tarihinde Türkiye'den ve dünyanın çeşitli yerlerinden gelen 350.000 kişinin iştirak ettiği Cuma namazı ile cami hüviyetini tekrar kazanmıştır.

\section{Doğu/İslam Medeniyeti ve Batı/Hristiyan Medeniyeti İçin Ayasof- ya'nın Anlamı}

Mekân ve medeniyet ilişkisinde mekân, medeniyetin var oluş ve etki alanı olarak ortaya çıktığı dış sınırları ifade etmektedir (Enser, 2018, s.270). Medeniyetler kendilerini mekân üzerinden kalıcı kılmak isterler. Mekânın süreklilik özelliği de toplumsal hafızaya işlediği kodlar aracıllğıyla medeniyetin geçmişle bağını koparmadan geleceğe bağlanmasını sağlamaktadır. Medeniyetin var kıldığı mekân geri dönüşlü olarak medeniyeti üreten ve besleyen katkılar sunarak bir medeniyetin sembolü 
haline gelir. Medeniyetlerin belirli bir mekân için mücadele etmelerinin temel nedenlerinden biri de mekân üzerinde kurdukları hâkimiyet ve denetim ile birbirleri üzerinde de hakimiyet ve denetim kurma arzular1dir.

Medeniyetler tarihsel süreç içinde çeşitli sebepler neticesinde birbirleri ile etkileşim içinde olmuşlar ve birbirlerinden her alanda çok şey alıp vermişlerdir. Dolayısıyla bütün bir medeniyetler tarihini çatışma ve mücadele alanı olarak değerlendirmek doğru olmamakla birlikte dünya görüşlerindeki temel farklılıklar medeniyetleri çoğu kez karşı karşıya getirmiştir.

Cemil Meriç (2004, s.202) Türk İslam medeniyeti ile Hristiyan Batı medeniyetinin farklı bakışlara (özellikle insana bakışlarında) sahip çarp1şan iki medeniyet olduklarını ifade etmektedir. Bu minvalde medeniyetin var oluşunu ve etki alanını sembolize eden Ayasofya hem Doğu/İslam medeniyeti hem de Batı/Hristiyan medeniyeti için büyük anlamlara sahiptir.

Bizans İmparatorluğu'nun resmi din olarak Hristiyanlı̆̆ 1 kabul etmesinin ardından inşa edilen Ayasofya, Bizans'ta hâkim olan pagan inanc1na karşı Hristiyanlığın muzafferiyetinin sembol mekânı olmuştur. Bununla birlikte Bizans krallarının Ayasofya'da bulunan omplihalionda taç giymesi ile iktidarı meşrulaştıran siyasi bir semboldür (Güney, 2020, s.112).

İstanbul'un fethi ile cami olan Ayasofya, Osmanlı İmparatorluğu içinde dini ve siyasi işlevleri olan sembolik bir mekân olma özelliğini korumuştur. Ancak Ayasofya'nın, İslamiyet'in Hristiyanlığa karşı galibiyetini somutlaştıran bir mekân olma (Güney, 2020, s.112) ve Müslüman Türklerin bu coğrafyada medeniyetin el değiştirmesine vurdukları mühür anlamı her nevi anlamının önüne geçmektedir.

Ayasofya'nın dini anlamı ve önemi Bizans ve daha sonraki dönemlerde olduğu üzere diğer bazı kiliseler gibi Hz. Meryem'e, Hz. İsa'ya veya herhangi bir azize ithafen yapılmayıp doğrudan kutsal hikmetin, Tanrı'nın mekânı (Dursun, 2020, s.44) olarak yapılmasından ileri gelmektedir.

Tanrı'nın mekânı olan Ayasofya'nın kiliseden camiye çevrilmesinin yapılış amacına ters düşmediğini ifade eden Karakoç'a göre Ayasofya yapıldığında vahdet dini Hristiyanlıktı. İslam'ın ortaya çıkmasıyla bu 
muhteşem mabet, Allah'ın ismini ortak koşmadan haykırmaya ve en yüce dinin mabedi olmaya daha uygun olmuştur. İşte bu sebeptendir ki Fatih, dinin saf halindeki mevcudiyetinin tapınağ 1 olsun diye Ayasofya'yı cami yapmıştır (Karakoç, 1990, s.14).

İstanbul'un fethi Bizans için sadece toprak kaybı ve siyasi bir hezimeti değil din merkezli bir medeniyetin yenilgisi anlamına da gelmektedir. Ayasofya'nın cami olmasının ardından, Fatih'i kastederek “...Deccal'in mübeşşiri, mihraptaki mukaddes din taşının üstünde namazını kıldı. Nedir bu nekbet? Ey güneş titre! Bu mihrap üzerinde kurban olan, yenilen ancak hiçbir vakit tükenmeyen Baba'nın oğlu nerede? Allah'ın hikmeti namına bina olunan bu mabet, bugün barbarlarm ibadet yeri oldu ve Muhammed'in evi adın ald $\imath^{\prime \prime}$ sözleri ile üzüntüsünü dile getiren Bizans tarihçisi Dukas (1956, s.184) Hristiyan Batı'nın Müslüman Doğu'ya bakışını ve iki medeniyet arasındaki mücadele tarihini özetlemektedir.

Fatih Sultan Mehmet, İstanbul'u fethettikten sonra Ayasofya'ya ganimet olarak yaklaşılmasına müsaade etmemiştir. Ayasofya'da kılınan ilk namazın ardından Bizans döneminde oldukça yıpranan yapıyı onarmış, mabedin içindeki mozaikleri, resimleri bozmadan üstlerini kapatarak cami hüviyetini kazandıracak mimari eklemeler yapmıştır. Fatih'ten sonra gelen Osmanlı padişahları da aynı hassasiyeti göstererek Ayasofya'nın karakteristik özelliklerini koruyarak günümüze kadar ayakta kalmasını sağlamışlardır. Yıl 1912 olduğunda İstanbul'a gezmek için gelen gazeteci heyetinin içinde yer alan Stephane Lausenne, Ayasofya ile ilgili izlenimlerini 10 Aralık 1912 tarihli Matin gazetesinde yazarken “...Ayasofya Türklerin mabetlere karşı saygısının tezahürüdür. Ayasofya bozulmamış, onarılmıştır" sözleri ile bu gerçeği teslim etmiştir. Ancak gazeteci, fethin ardından geçen 459 senenin sonunda Ayasofya'nın Şark medeniyetini sembolize eden bir mekân olmadığını “...İçeride İslamiyet vardı ama o, sadece kiracıydı. Müslümanlar mozaikleri kapatmışlar, mihrabı inşa etmişlerdi ama ev sahibi olamamışlardı. Tarih onlara zafer olarak Ayasofya'yı inşa etmeyi nasip etmemişti..." (Bardakçı, 2006, s.7071) ifadeleri ile aktarmaktan da geri kalmamıştır.

Batı/Hristiyan medeniyeti için 1453 'ten kalma saklı yara I. Dünya Savaşı'ndaki mağlubiyetten sonra Mondros Mütarekesi gereğince İstanbul'un işgali sağlandıktan sonra açığa çıkmıştır. Savaşın galipleri olarak Batılı devletler ve Osmanlı topraklarındaki azınlıklar Ayasofya'ya dair 
emellerini gerçekleştirmek için çeşitli faaliyetlerde bulunmuşlardır. İngiliz Başbakanı Lloyd George, 2 Ocak 1918'te yapılan memorandumda, “... Ayasofya, dokuz yüzyıl önce bir Hristiyan kilisesi idi, tabiatıla eski hüviyetine iade edilecektir" ifadelerini kullanmış ( Jaeschke, 1991, s.52) ve bu sözleri ile savaşa dâhil ettikleri Yunan askerlerine ve İstanbul'daki Rum azınlıklara cesaret vermiştir.

İşgal kuvvetlerinin ve azınlıkların art niyetli çalışmaları farklı Meclis-i Vükelâ toplantılarında görüşülmüş ve Osmanlı hükümeti Ayasofya ile ilgili birtakım önlemler almıştır. Bu önlemlerden ilki Ayasofya'nın civarındaki toprak ve mekânların yabancılara satılmasını yasaklayan düzenlemelerdir.

Ayasofya'nın Türk-İslam dünyasında kalabilmesi için Osmanlı hükümetinin aldığı en önemli tedbir ise şu şekilde cereyan etmiştir. İstanbul'un işgalinde Fransa Ayasofya'nın patrikhaneye ve Yunanistan'a verilmesi ve ardından kiliseye çevrilmesi niyetini gerçekleştirmek üzere bir Fransız taburunu Ayasofya'ya yönlendirecek ancak işgal kuvvetlerinden daha önce hamle yapan Osmanlı hükümetinin Ayasofya camine yerleştirdiği Binbaşı Tevfik Bey'in komutasındaki bir tabur asker ile karşılaşacaktır. Tevfik bey, Fransız komutana camiyi boşaltmayacaklarını, ısrar edip içeriye girmek isterlerse camiye yerleştirdikleri bombaları patlatacaklarını, bu kutsal mabedin yıkıntıları altında öleceklerini ama onların bu mabede asla giremeyeceklerini ifade etmiş, caminin etrafında günlerce bekleyen Fransız askerleri, Türk askerlerinin mabedi namahremin eline teslim etmektense havaya uçuracaklarını kani olan Fransız hükümetinin emriyle geri çekilecektir (Akgündüz vd., 1994, s.386-387).

Türk-İslam medeniyetinden koparılmasını onun yıkılmasından daha büyük bir tehlike ve kayıp olarak kavrayan bir tabur Türk askerinin kararlılığıyla Ayasofya, İstanbul'un işgal yıllarında dahi Fatih'in "Ayasofya-i Kebîr Cami-i" si olarak kalmıştır. Çünkü Ayasofya, "Doğu- Batı tarihinde zaferin hangi tarafta kaldığının bir sembolüdür. Ayasofya cami olduğu sürece üstünlük İslam'dadır. O, cami olmaktan çıktığı andan itibaren bu üstünlüğün Batı'da olduğu itiraf edilmiş olmaktadır" (Karakoç, 1990, s.13).

1923'te muasır medeniyetler seviyesine ulaşmak için yönünü Batı'ya dönmüş yeni devlet için Ayasofya'nın medeniyetsel anlamı "mana" dan arındırılıp seküler bir mekân anlamı kazanacaktır. Ayasofya'nın 1934 
yılında bir Bizans müzesi olarak kurgulanması Doğu/İslam medeniyetinden kopmanın ve çağdaş Batı medeniyetine katılmanın ideolojik karakterini de resmetmektedir.

Ayasofya'nın müze olmasını bir medeniyetin varoluşsal kaybı olarak değerlendiren Kısakürek, meşhur Ayasofya Hitabesinde "Ayasofya, yirminci asır dünyasina gerçek medeniyet ve ebediyet mimarisinin ne olduğu gösteren Batı aklı ve Doğu ruhunu birleştiren bir kubbedir. Ayasofya madde uyumu değildir. O, sadece mânadır. Her mana, her hikmet, her münasebet Ayasofya'ya bağhldır. Ayasofya Müslüman Türklerin bu coğrafyada varlığının remzidir" ifadelerini kullanacak ve Ayasofya'nın bir gün mutlaka cami olarak ibadete açılacağını, o vakte kadar kaybedilen bütün manaların onun içinden fışkırıp gün yüzüne çıkacağını vurgulayacaktır (Kısakürek, 2016, s.156-160).

Benzer şekilde Peyami Safa'da, "Fatih'in Ayasofya minarelerinden yükselen ezan sesinin İstanbul'da İslam-Türk hakimiyetini ebedileştireceğini bildiğini, beş asır sonrasında torunları arasında bunu unutacakların çıkacağını tahmin bile edemeyeceğini" (Safa, 1990, s.196) söyleyerek Ayasofya'nın mekân ve medeniyet bağlamında önemli bir sembol olduğunu dile getirecektir.

Ayasofya'yı kilise yapma konusunda başarılı olamayan, en azından müze olması ile teselli bulan Batı, Ayasofya'yı kilise olarak görme arzusundan hiçbir zaman vazgeçmemiştir. 1955 yılında Münih'te gerçekleştirilen Byzantinistler Kongresi'nde Alman Kardinal'in “Ayasofya'nın kubbesinde Bizans yıldızı parlamaktadır ve sonsuza kadar parlayacaktır" (Kandemir, 2005, s.21) ifadeleri ve Rus Patriği III. Aleksi'ye Altunç Altındal tarafından sorulan "Sizin için Ayasofya'nın anlamı nedir?" sorusuna "Kâbe Rus çizmesi altında olsaydı siz ne hissederseniz biz de Ayasofya'nın üzerinde o bayrağı gördükçe onu hissediyoruz" (Çebi, 2006, s.71) cevabı Ayasofya'nın Bizans ve Hristiyan medeniyetinin temsili olarak görülmeye devam ettiğinin örnekleridir. 20. yüzyılda Hristiyan din adamlarının dudaklarından dökülen bu sözler; 19. yüzyılda Osmanlı'nın askeri gerileyişinden istifade edilerek Rusları Osmanlı İmparatorluğuna savaş açarak tüm Slavları birleştirmeye davet eden Dostoyevski'nin “Doğuda yaşatılan İsa gerçeğinin yeniden yükselişi, İsa haçının yeniden Ayasofya'ya dikilmesi ve başında uzun zamandan beri Rusya'nın bulunduğu Ortodoksluğun son sözü olacak- 
tır."(http://www.agos.com.tr/tr/yazi/27-69/dostoyevskihayallerindeayasofyayi-yeniden-haclandirmis) cümlelerinin uzantısıdır.

Batı/Hristiyan medeniyeti, Ayasofya için yakın tarihli hamlelerinden birini de 2002 yılında adeta Türkiye Devleti'nin bağımsızlığını yok sayarak yapmıştır. Avrupa Konseyi Karma Parlamenterler Meclis Üyesi Corneliu Vadim Tudor, 1 Şubat 2002 yılında Türkiye yetkililerinin Aziz Sophie katedralini Hristiyanlığa teslim etmesi gerektiği ifadelerini taşıyan önergesini Avrupa Karma Parlamenter Meclisine sunmuş ancak talebi dikkate alınmamıştır (https://pace.coe.int/en/files/9628 ).

Danıştay 10. Dairesi 10 Temmuz 2020 tarihinde Danıştay 10. Dairesi'nin, 24 Kasım 1934 yılında Bakanlar Kurulu'nun Ayasofya'yı müzeye dönüştürme kararının iptalini açıklamasının ardından Batı dünyasından karara ilişkin tepkiler gelmiştir. ABD Dışişleri Bakanlığı, Rus Ortodoks Kilisesi, Avrupa Birliği Danıştay’ın kararından duydukları hayal kırıklı̆̆ı ve üzüntüyü dile getirirken Yunanistan Başbakanı Kiryakos Miçotakis ise "Ayasofya'nın camiye dönüştürülmesi kararı tüm uygar dünyaya karşı açık bir provokasyondur." ifadelerini kullanmıştır. UNESCO ise Ayasofya'nın Dünya Kültür mirasını yeniden gözden geçireceğini belirterek(https://www.dunya.com/gundem/ayasofya-ile-ilgilidunyadan-ilktepkiler-haberi-474885) Türkiye' yi üstü örtük bir şekilde tehdit etmiştir.

Katoliklerin ruhani lideri Papa Francis ise 12 Temmuz'daki Pazar Ayininde "Deniz aklımı uzaklara götürüyor, İstanbul'a. Ayasofya'yı düşünüyorum ve büyük acı duyuyorum" (Görmez, 2020, s.23) sözleri ile Ayasofya'nın Batı/Hristiyan medeniyeti için anlamını bir kez daha ikrar etmiştir.

İslam dünyasında ise Danıştay'ın Ayasofya ile ilgili kararı desteklenmiş ve sevinçle karşılanmıştır. İslam dünyasında çıkan haberlerde ve çeşitli akademisyenlerin beyanatlarında Ayasofya'nın ibadete açılmasından tüm Müslümanların gurur duyduğu, İstanbul'un fethi ile ilişkinin yeniden canlandırıldığı vb. ifadeler yer almaktadır. Moritanyalı akademisyen Muhammed Muhtar Şankıti, Twitter hesabından yaptığı açıklamada, Ayasofya'nın ibadete açılması dolayısıyla İslam âlemini kutladığını belirtmiş ardından Ayasofya'da bale yapıldığı ana dair bir fotoğrafı ${ }^{2}$

\footnotetext{
25 Ocak 2019'da gerçekleşen akşam açılışında bir bayanın bale figürü yapması ve bu anın iş kadını Leyla Alaton tarafindan karelenip fotoğrafları sosyal medya hesaplarında paylaşması sonucunda gelişen tepkiler
} 
da paylaşarak “Türkiye'de ve İslam dünyasında tepkiyle karşılanan bu durumun artık yaşanmayacağını ve Ayasofya'nın özüne döndüğünü" ifade etmiştir (https://haberglobal.com.tr/dunya/ayasofya-kararinadunyada-kimler-destek-verdi-57659).

Ayasofya'nın açılışı Türk düşünce dünyasında da çift yönlü yankılar uyandırmıştır. Danıştay'ın kararını eleştirenlerin sesi 24 Temmuz'da İstanbul'da yankılanan tekbir seslerini bastıramamıştır. "Tekbirler... dedeleri Fatih Sultan Mehmed Han sandukasının kapağını araladı, kendisine kadar okyanus dalgaları gibi çağlaya çağlaya gelen bu sesi memnun ve mesrur dinledi. Bugün Ayasofya çoğaldı, mümin alınların Rab'leri katında hamd ve tesbihat hisleri ile secdeye konduğu bütün mescitler bir Ayasofya oldu" (And1, 2020a, s.8).

24 Temmuz 2020 Cuma günü Diyanet İşleri Başkanı Ali Erbaş'ın Cuma hutbesini bir kılıca yaslanarak okuması da Ayasofya'nın Türk-İslam medeniyeti için anlamını tüm dünyaya göstermesi açısından manidardır. Hz. Peygamberin sünneti doğrultusunda İstanbul'un fethinden sonra Ayasofya'da yıllarca Cuma hutbeleri k1lıca dayanarak okunmuştur. Dolayısıyla Diyanet İşleri Başkanı Ali Erbaş'ın hutbe okurken yaslandığı kılıç Fatih'in İstanbul'un fethinde kullandığı kılıcı temsil etmektedir (Öztoprak, 2020, s.28-31).

Ayasofya'nın 86 yıldan sonra cami hüviyetini kazanması Türk toplumunun büyük çoğunluğunda büyük anlamlara gelmektedir. Ayasofya'nın açılmasının önemi sadece ibadet mekânı vasfını kazanması ile açıklanıp yeterli görülmemelidir. Ayasofya davası şimdi yeniden başlamaktadır. Medeniyet çevresinde Ayasofya-i Kebir'in açılması ve ilk namaz konjoktür ve paradigma kaydırıcı, yapıyıkıcı tarihî bir dönüm noktası olabilmelidir. Bu ise kolektif failin irade kuvvetine ve çalışıp gayret etmesine bağlıdır (Andı, 2020b, s.23-25).

\section{Osman Yüksel Serdengeçti ve Ayasofya}

Asıl adı Osman Ziya Yüksel olan Serdengeçti, 1917'de Akseki'de doğmuştur.1974 yılında Parkinson rahatsızlığına yakalanmış, 10 Kasım 1983'te Ankara' da vefat etmiştir. 
Modernizme, Batılılaşmaya, materyalizme karşı olan Osman Yüksel tek parti döneminin bu çizgideki uygulamalarına karşı çıkmış ve sürekli mücadele içinde olmuştur. Dönemin baskı koşullarına rağmen yapılan uygulamalara cesaretle karşı koyduğu için dergisinin adını Serdengeçti koymuş ve şahsiyeti bu isimle birleşmiştir. Onun davası İslam'ı, Türk milliyetini, tarih ve gelenekleri, mukaddesatı ve dince kutsal sayılan değerleri savunmaktır (Karaçam, 2009, s.555). Serdengeçti, açık sözlü, cesur karakteri ile inandıklarını müdafaada iktidarın baskısına boyun eğmemiş, hakkın yanında halkın sesi olmaya çalışmıştır.

Milliyetçi, muhafazakâr, İslamcı olarak değerlendirilen ${ }^{3}$ davasında, hakkında 92 kez dava açılan, (kendi deyişiyle) sekiz defa mahpus bir kere mebus ${ }^{4}$ olmuş (Böcü, 1997, s.137) Serdengeçti, Türk toplumunun tarihine, kültürüne, geleneklerine, İslam'ın değerlerine uygun olmadı̆̆1nı düşündüğü her türlü gelişmeye karşı durmuştur. 1947-1962 yılları arasında ancak 33 sayı çıkartabildiği Serdengeçti dergisinde kaleme aldığ1 yazılarında siyasal iktidarın hedefi olmuş ancak "karasevdalısı olduğu büyük İslam ve insan davasından” (Balcıoğlu, 1991, s.276) vazgeçmemiştir.

1952 y1lında Türkiye'ye gelen Rum Patriği Athenegaros'un bir devlet adamı gibi karşılanmasından, ülke içindeki Rumların ve Yunanistan basınında Ayasofya'nın aslına uygun olarak kilise yapılması ile ilgili neşriyat ve faaliyetlerinden dolayı şiddetli bir dini/milli endişe yaşayan Serdengeçti, "Ayasofya" başlıklı bir yazı kaleme almıştır. Yazı Serdengeçti dergisinin Ağustos-1952 tarih ve 17. sayısında neşredilmiştir.

Ayasofya yazısının yayınlanmasından 3 ay sonra Milli Müdafaa Vekaleti'nin 19.11.1952 tarih ve 52/6470 sayılı takip izni yazısı gereğince 23.01.1953 tarihinde Ankara Garnizon Komutanlığı tarafından Serdengeçti hakkında ilk soruşturma başlatılmasına karar verilir. İlk tahkikat ve bilirkişi raporunun ardından "milli mukavemeti kırmak, Türk-Yunan dostluğunu ihlal etmek" iddiası ile TCK'nın 161. ve 163. maddesi kapsamı ile Ankara Ağır Ceza Mahkemesinde dava açılır. Savcı, Serdengeçti için idam talep eder. Serdengeçti bu davadan Ankara 2. Ağır Mahkeme-

\footnotetext{
3 N.F. Kısakürek, 1952 yılında gazeteci Ahmet Emin Yalman'ın vurulması ile "gençleri kışkırtmak" suçuyla birlikte yargılandı̆̆ı ve yakın dostu olan Serdengeçti'yi “.... Eski Türkçü ve yeni İslamcı" olarak değerlendirmektedir.(Bkz: Necip Fazll Kısakürek, Babıâli, 2011/Büyük Doğu Yayınları.)

${ }^{4} 1965$ seçimlerinde Adalet Partisi'nden Antalya milletvekili seçilmiştir.
} 
si'nde 11.07.1953 tarihinde verilen karar ile beraat etmiştir (Akyüz, 1959, s. 11-14-62).

Osman Yüksel Serdengeçti, derginin Mayıs-1956 tarihli 22. ve Haziran-1959 30. sayılarında mahkeme sürecindeki müdafaasını ve fethin 500. yıl dönümü hasebiyle kaleme aldığı Ayasofya başlıklı yazısını yeniden yayınlayacak ve "tarihin affetmeyeceği bu dava ${ }^{5}$ " üzerinden Ayasofya'nın önemini bir kez daha toplumsal hafızada tazeleyecektir (Serdengeçti Dergisi, 1956, s.5-7; 1959, s.2-4).

Çalışmamızda esas alınan ve Serdengeçti'nin tutuklu yargılanmasına sebep olan yazının tam metni şöyledir (Serdengeçti, 1952a, s.3).

AYASOFYA

“Ey İslam'ın nûru, Türklü̈̆̈̈̈n gururu Ayasofya!. Şerefelerinde fethin, Fatih'in şerefi ışıl ışıl yanan muhteşem mâbet!...

Neden böyle bomboş neden böyle bir hoşsun?!... Hani minarelerinden göklere yükselen, tâ mâveradan gelen ezanlar?!... Hani o ilahi devir, ilahi nizamlar?!...

Ayasofya ses vermiyor, Ayasofya bomboş, Ayasofya bir hoş!...

Hani nerde, şu muhteşem minberde, binlerce erin, binlerce gazinin baş koyduğu şu temiz yerde, şimdi hangi kirli ayaklar dolaşıyor!. Ayasofya seni bu hale koyan kim; seni çırılçılak soyan kim?

Hani kubbelerden gönüllere, gönüllerden kubbelere gürül gürül akan, sineler yakan Kur'an sesleri...

Kur'an sesleri dindirilmiş, Müslümanlar sindirilmiş, Allah, Muhammed, hülâfa-i raşidin, bu din ulularının isimleri kubbelerden yerlere indirilmiş!...

Fethin Fatih'in mabedinden kitabı mübini, bu ulu dini, kaldıran kim? Dinimize, imanımıza saldıran kim?!...

Astrlık surların arkasından köhne Bizans'ı hortlatmak isteyen eller kimin eli, bunu söyleyenler kimin dili, Ayasofya'yı puthane yapan hangi delidir?!...

Elleri kurusun, dilleri kurusun... Ayasofya Ayasofya seni bu hale koyan kim?. Seni çırılçılak soyan kim?

Ayasofya! Ey muhteşem mabet! Merak etme, Fatih'in torunları yakında bütün putlar devirip seni camiye çevirecekler. Gözyaşlarıla abdest alarak secdeye kapanacaklar... Tehlil ve tekbir sadaları boş kubbelerini yeniden doldura-

\footnotetext{
${ }^{5}$ Osman Yüksel'in avukatlarından Arif Emre, Ayasofya davasındaki savunmasinda "Bu dâvanin bir zühul neticesinde açıldığın kabule çalışarak bizler durumu mazur görsek bile tarih bu hatayı affetmeyecektir" ifadelerine yer vermiştir (Akyüz, 1959, s.35).
} 
cak...ikinci bir fetih olacak...Ozanlar bunun destaninı ezanlar bunun ilanin yapacaklar...Sessiz ve öksüz minarelerinden yükselen tekbir sesleri fezaları inletecek... Şerefelerin yine Allah'ın ve O'nun sevgili Peygamberi Hz. Muhammed'in şerefine ışıl ışıl yanacak... Bütün dünya Fatih dirildi sanacak. Bu olacak Ayasofya, bu olacak!... İkinci bir fetih, yeni bir basübadelmevt... bu muhakkak. Bu günler yakın, belki yarın, belki yarından da yakın."

\section{Medeniyet-Mekân Bağlamında “Ayasofya" Yazısının Tahlili}

Serdengeçti, "Ayasofya" yazısının giriş cümlelerinde mekânı inanç yönüyle öne çıkartmaktadır. Serdengeçti, mekâna maddi ve manevi unsurları dâhilinde bütünsel olarak bakmış ve bu unsurları yazısında medeniyet anlamlarını, izlerini yansıtacak şekilde işlemiştir.

Serdengeçti, yazısına "Ey İslam'ın nuru, Türklü̈̆̈̈̈n gururu Ayasofya!..." hitabı ile başlayarak mekânın Türk-İslam medeniyetine ait bir mabet olduğunu ve sembolik anlamını ikrar etmektedir. Mekânın maddi unsurlarından İslam dinini karakterize eden minare, kandil ve şerefelerini ele alan yazar ışıl ışıl yanan bu muhteşem mabetin tarihselliğini Fatih ve fethin şerefine bağlayarak okuyucunun aynı hissiyatı yaşamasını sağlamıştır.

Ayasofya'nın tarihi ve siyasi anlamları parantez içine alınıp yalın bir sanat eseri olarak değerlendirildiğinde Bizans döneminin mimari ve süsleme teknikleri ile estetik değeri yüksek bir yapıttır. Ayasofya, altın ve gümüş süslemeleri ile Batı medeniyetin maddi âlem anlayışını ve 'göz' duyusuna verdiği kıymeti yansıtırken, Hz. Meryem'e, Hz. İsa'ya ve azizlere ait resimler, ikonlar ve kutsal eşyalarla Hristiyan medeniyetinin inancını, uhrevi âlem anlayışını yansıtmakta ve Hristiyanların ruhlarına hitap etmektedir (Aslan, 2009, s.29).

Ayasofya'nın dış mekân özellikleri oldukça sade tutulmuştur. Çünkü Ayasofya' da 'azamet' iç mimaride verilmek istenmiştir. Ayasofya'nın iç mimarisinde kullanılan görkemli sütunlar Misır, Heliopalis, Ephesos, Artemis gibi antik medeniyetlerden ve kentlerden getirilmiştir. Ayasofya'daki çeşitli renk ve biçimlerden oluşan mermerlerde farklı bölgelerden temin edilmiştir (Aslan, 2009, s.29). Ayasofya'nın sütunları ve mermerleri Bizans'ın azametini, bolluğunu tebaasına ve yabancılara göstermek için özenle seçilmiş figürlerdir. 
Ayasofya'nın ihtişamına ihtişam katan Bizans dönemi mimari özelliklerinden biri de sahip olduğu kapılardır. Bugün bazıları kapatılmış olmakla birlikte pek çok kapısı bulunmaktadır. İç narteksten Ayasofya'ya girmeyi sağlayan, sadece imparator ve mahiyeti tarafından kullanıldığ 1 için "İmparator Kapısı" olarak adlandırılan en büyük kapısı 7 metre yüksekliğinde ve çerçevesi bronzlarla kaplıdır (İkinci, 2014, s.50).

Ayasofya'nın mimarisi hakkında öne çıkan bu özellikler mekânın maddi unsurları olarak birçok şiir ve nesre konu olsa da Serdengeçti'nin yazısında işlenmemiştir. Ayasofya Bizans tarafından Bizans mimari anlayışı ile yapılmış olsa da Serdengeçti, Ayasofya' yı uyumlu maddelerin toplamından çok bir mana-ruh, bir eylem mekânı ve bir inancın sembolü olarak görmektedir. Serdengeçti için Ayasofya İslam mimarisi ile üflenen nefes ile can bulmuş, hikmete ram olmuş yepyeni bir mekândır. "İslami akideler, İslam'ın kozmolojik telakkileri ve tevhid anlayışı bağlamında İslami tavirlar İslam mimarisinden yansiyarak" (Cansever, 2010, s.17) Ayasofya' da vücut bulmuştur.

İstanbul'un 29 Mayıs 1453'te fethinden sonra 1 Haziran 1453'te k1lınacak olan ilk Cuma namazına yetişmesi için Fatih tarafından yapılan ilk eklemeler mihrap ve minber olmuştur. Caminin mihrap ve minberleri dönem dönem Osmanlı padişahları tarafından onarılmış ve eklemeler yapılmıştır. III. Murad döneminde mihrap beyaz mermerden yenilenmiştir.

Ayasofya'da kılınan ilk Cuma namazından önce Fatih ahşap minberde kılıca yaslanarak hutbeyi okumuştur. Ayasofya, fetih hakkı bir başka deyişle kılıç hakkı olarak kiliseden camiye çevrildiği için kapatılıncaya kadar hutbeye kılıç ile çıkılmıştır (Akçay, 1999, s.118). Türk-İslam medeniyeti geleneğinde kılıç, gücün temsili, fethin alameti, fetih ruhunun devam ettiği, adaletin tesisi, müslim ve gayrimüslim halkın güvenliğinin teminatı (Öztoprak, 2020, s.28) anlamlarına gelmektedir.

Serdengeçti yazısında minberden bahsetmekle birlikte açık bir şekilde Fatih'in minberde k1lıca yaslanarak ilk hutbeyi okuduğunu aktarmamıştır. Ancak minberin bu anlamı Serdengeçti'nin Ayasofya yazısına istinaden hakkında açılan davanın savunmasında dile getirilmiştir. "Ayasofya'nın bir deori açıp bir devri kapatan Fatih'in ilk hutbeyi okuduğu mabed olarak İslam-Türk âleminde bambaşka bir yeri vardır." (Akyüz, 1959, s.52) diyen 
Serdengeçti için Ayasofya, kılıçla fethedilen İstanbul'un İslam ruhuyla yeniden fethedilmesidir.

Ayasofya' nın cami hüviyetini kazanmasını ve İslam medeniyetine aidiyetini temsil eden en önemli maddi unsuru minareleridir. Fatih tarafından yapılan ilk minare uzun müddet durmuş, ancak 1574 tamirinde kaldırılmıştır. Caminin güneybatı köşesindeki (kırmızı renk) tuğla minarenin Fâtih devrine ait olduğu söylenirse de bunun II. Bayezid zamaninda yapılan minare olması ihtimali daha kuvvetlidir. II. Selim döneminde güneydoğu cephesine bir minare ve III. Murad döneminde ise kuzey yönünde iki minare daha eklenmiştir (Eyice, 1991a, s.208).

Ayasofya'nın en önemli maddi unsuru şüphesiz ki kubbesidir. Kubbe, sözlükte "kavisli, gömbeli, yuvarlak dam” (Mülayim, 2002,s. 300) anlamlarına gelmekte ve Doğu mimarisinin temel yapı unsurlarından biri olarak kabul edilmektedir. Ayasofya'nın mimarisi Hristiyan mabetlerinin genel planı olan bazilika tarzına göre yapılmış olsa da mimari planına zeminden yüksekliği 55 metre olan ve çapı ortalama 31-33 metreyi bulan kubbe önemli bir farklılık olarak eklenmiştir (Eyice, 1991a, s.207).

"Kurşun Kubbeler Şehri" olarak anılan İstanbul'daki tarihi camilerin içinde en geniş ve yüksek kubbeye sahip olan Ayasofya'dır. Ayasofya sadece Osmanlı sınırları içinde değil dünya ölçeğinde 15. yüzyıla kadar Pantheon'dan sonra en geniş kubbeye sahip bina olma özelliğini korumuştur (Güney, 2020, s.141-142).

Serdengeçti'nin yazısında Bizans dönemine ait kullandığı tek mimari öğe Ayasofya'nın kubbesidir. Tarihin erken dönemlerinde ve çeşitli medeniyetlerde kullanılan kubbenin asıl gelişimi Türk çadırlarıyla stupa ve ateşkedelerden yola çıkan mimarların çabalarıyla Doğu medeniyetinde gerçekleşmiş en ince hali ise Türk İslam mimarisinde ortaya konulmuştur (Mülayim, 2002: 300). Dolayısıyla Serdengeçti için “kubbe”nin kökeninin Bizans/Batı mimarisine ait olmayıp "Orta ve Ön Asya' dan dünyaya yayılan, gökkubbeyi temsil eden Türk kubbesine (topak ev)" (Mülayim, 2002, s. 301 ) dayandı̆̆ını söyleyebiliriz.

Serdengeçti'nin yazısında Ayasofya'nın maddi mekân unsurlarından Türk-İslam medeniyeti ile bütünleşmiş olanlarını yine bu maddi öğelere İslam'ın uhrevi kıymetlerini ve fetih anlamlarını da katarak vurgu yapmayı tercih ettiği söylenebilir. Nitekim, Ayasofya davasının 11.07.1953 
tarihinde yapılan duruşmasında Serdengeçti'nin avukatı Mehmet Emin Akyüz savunmasında yorumumuzu destekleyen şu ifadeleri kullanmıştır. “....Ayasofya'nın temelinden zirvesine kadar bütün maddi varlı̆̆ını Müslüman-Türk hüviyetiyle sarmış, bu maddi varlığ1 Türk-Müslüman kimliğinden ayrılmaz ve tecezzi kabul etmez hale getirmiştir. Anadolu'dan Türklük vasfı giderilemezse, Ayasofya'dan da Türk-Müslüman hüviyetinin manası öylece silinemez." (Akyüz, 1959, s.39).

Serdengeçti'nin yazısında Türk-İslam mimarisinin özelliklerini öne çıarmasının bir diğer nedeni de 02.04.1953 tarihli duruşmada Ayasofya ziyaretinde karşılaştığı manzarayı tasvir ettiği savunmasında saklıdır. "Bizans devrine ait ne varsa, büyük bir itina ile ortaya çıartılmış, bizden olan, bize hitap eden her şey imha edilmiştir. Ayasofya şimdiki haliyle içinde mum yanmayan, istavroz, günah çıarılmayan bir kilisedir. Elbette Müslüman bir Türk olarak bundan hüzün duydum. Acı duymak hakkımızda mı yok!" (Akyüz, 1959, s. 58).

Serdengeçti Ayasofya'nın Türk-İslam hüviyetinden kopartılıp Bizans'a ve onun torunları olan Batıya sunulduğunu "Asırlı surlarm arakasindan köhne Bizans'ı hortlatmak isteyen eller kimin eli, bunu söyleyenler kimin dili, Ayasofya'yı puthane yapan hangi delidir?..." sözleri ile anlatmıştır.

Bu cümleler sadece Serdengeçti'nin coşkulu ve sitemkâr duygularından değil tarihi yaşanmışlıklardan kaynaklanmaktadır. Ayasofya Aralık 1934 tarihinde Müzeler Genel Müdürlüğü'ne devredilir. Müzeler Genel Müdürlüğü, Ayasofya'yı şöhreti ile uygun bir Bizans müzesi olacak şekilde onarmayı kapsayan bir proje hazırlamıştır. Bu proje kapsamında Arkeoloji Müzesinde bulunan ambonlar, lahitler, Bapsisterler ve Nur-u Osmaniye Camii avlusunda kırmızı porfirden lahit ile Zeyrek Camii önündeki lahit vd. Büyük Bizans eserleri Ayasofya'ya taşınarak sergilenmiştir.

Osmanlı İmparatorluğu için İstanbul ve Ayasofya çok önemlidir. Bu öneme haiz olarak Ayasofya, onu diğer mabetlerden farklı kılacak asma kandiller, özel duvar saatleri, halılar, rahleler, kıymetli Kuran-1 Kerim yazmaları ve sakal-ı şerif gibi değerli eşyalarla donatılmıştır. Müze olduğunda bu kıymetli eşyalar nem ve rutubetten çürümeye terk edilecek depolara kaldırılmıştır. Ayasofya'nın önce halıları sökülmüş bu halıların bir kısmı Edirne camilerine gönderilmiştir (Öztürk, 1995, s.503). Ayasof- 
ya'yı cami yapan bütün emareler yok edilirken Ayasofya'yı süsleyen bu kıymetli eşyaların önemli bir kısmı kaybolmuştur.

Serdengeçti, Ayasofya'nın Bizans eserleri ile bir yandan tanzim edilip doldurulmasını diğer yandan İslami eserlerin kaldırılmasını ve onu cami yapan elbiselerin lime lime edilip boşaltılmasını " Ayasofya seni bu hale koyan kim, Seni çırılçıplak soyan kim?" soruları ile kritik etmektedir.

"Kur'an sesleri dindirilmiş, Müslümanlar sindirilmiş, Allah, Muhammed, hülâfầ Raşidin bu din ulularmın isimleri kubbelerden yerlere indirilmiş!..." diyen Serdengeçti tek parti döneminin İslam dini ve Müslümanlar üzerindeki baskıcı uygulamalarını ve Ayasofya'nın müze olma aşamasında İslam'ın izlerini silme çabalarını eleştirmektedir. Ayasofya'da bulunan Allah, Muhammed ve dört halifenin isimlerinin yazıldı̆̆ 7,5 metre çapındaki hat levhaları Whittemore'un isteğiyle mekândaki yerlerinden indirilip Ayasofya'dan çıkarılmaya çalışılmıştır. Ancak bu muhteşem güzellikte ve büyüklükte olan levhalar zamanında cami içinde birleştirildiği için Ayasofya'nın kapılarından çıkarılamamıştır (Müftüoğlu, 1988, s.245). Ayasofya'dan çıkarılmak istenen dünyanın en büyük hat levhaları ödenek yok gerekçesiyle on beş yıl Ayasofya'nın içinde yerde duvara dayalı olarak bırakılmış ancak akli selim insanların maddi destekleri ile 28 Ocak 1949'da yerlerine asılabilmiştir.

Ayasofya'yı Türk-İslam medeniyetinden ve cami hüviyetinden arındırma arzusunun en akıllara sığmaz stratejisi ise minarelerinin yıktırılmasının düşünülmesidir. Ayasofya'nın civarında bulunan Bizans kilisesi iken II. Bayezid döneminde camiye çevrilen Küçük Ayasofya Cami'nin minaresi 1936 yılında herhangi bir gerekçe gösterilmeden yıktırılmıştır. Bu elim vakıanın yaşandığı günlerde Ayasofya-i Kebîr Cami'nin minarelerinin de yıktırılacağını İbrahim Hakkı Konyalı, mimar Kemal Altan ile sohbetinde öğrenmiş ve elindeki bütün imkânları kullanarak önlemiştir (Yakın Tarih Ansiklopedisi, 1989, s. 15).

Besim Dellaloğlu'na göre, Türk modernleşmesi yıkamadı̆̆ı geçmişi müze yaparak bugünden koparır. Ayasofya'nın müze olmasının mahiyeti de Ayasofya'yı var eden ve onda var olan medeniyetin tarihsel bütünlüğünü koparmaktır. Oysaki Ayasofya, tarihin yükünü taşıyan bir semboldür. Geçmişi bugünden kopardığınızda aslında geleceği bugünden bugünü ise hem geçmişten hem gelecekten koparmış olursunuz (Başaran, 2020, s. 48). 
Serdengeçti yazısında Ayasofya'nın tarihsel sürekliliğini kurmaya çalışmış ve mekânı öz kimliğindeki tasavvurlarından koparmadan tasvir etmeye çalışmıştır. Yazıda görülmektedir ki Ayasofya'nın göklere yükselen minareleri ta Mavera'dan gelen ezan sesleri ile birlikte verilmektedir. Ayasofya'nın minberi binlerce erin, binlerce gazinin secde ettiğgi an ile temiz kılınmaktadır. Ayasofya'nın kubbeleri sîneler yakan Kur'an sesleri ile gönüllere akmaktadır.

Mekânın tarihsel sürekliliğini sağlamanın etkin yollarından biri mekânın mazisine damga vuran aktörleri bugünden konuşturarak mekânın anlamını geçmiş ve şimdiki hal üzere tazelemektir. Serdengeçti dergisinin 15-16. sayısında "...Koca Fatih çok derinden asırların ve nesillerin arkasindan gelen bir sesle asrimiza neslimize seslenir .... Heyhat bana, heyhat asîl evladıma! Bu şehri görmek istemem artık. Ufuklara çevriliyorum. Bakışlarım daha uzaklara dalarak, düşman emelleriyle minarelerinde ezan sesleri susturulan Ayasofya'nm kubbesinden Irak ve Acem'in hudutlarma kadar bütün Anadolu'yu kucakladr. Nice yüz bin kanıyla üzerinde birlik kurduğumuz bu vatan ne kadar perişan olmuş! Ayasofya'nın minarelerinde okunan ezân, Allah'ın adı yanında Peygamber'in adını göklere dağıtırken ecdadına bağlı ruhlarda beni de düşündürüyordu da ondan mı? Bin haçlı ordusu bunları yapamazdı! Siz nasıl yaptınız?..." (Serdengeçti Dergisi, 1952b, s.3).

Serdengeçti'nin yazısında sorulan "Elleri kurusun, dilleri kurusun...Ayasofya seni bu hale koyan kim?" sorusunu Fatihin ağzından sorulan "Siz nasıl yaptınız" sorusu takip eder. Eylemin failini ve nasil cereyan ettiğini sorgulayan bu iki sorunun cevabı Ayasofya davasının 25.04.1953 tarihindeki savunmasında verilir. "Sayın savcımız, geçen celsede serdettiğ $i$ iddianamesinde, Ayasofya'dan bahsederken mütemadiyen, "aslinda kilise olan", aslında kilise olan" deyu kilise kelimesi üzerinde ısrarla durdu. Bana bu çok ağır geldi!. Muhterem savcımı, bırakalım bunu Rumlar söylesin. Biz Türk'üz, Müslümanız. Biz, bize yakışan söyleyelim. Bundan 1000 yıl evvel, Anadolu'ya 'Diyar-ı Rum' deniliyordu. Yoksa Ayasofya gibi bizim olan, bizden olan her şeyi yıkıp Anadolu'yu da tekrar Diyar-ı rum mu yapacağız. Athenagoras bunu duysaydı savcımızı alnından öperdi. Bu ne mantık, bu ne iş, bu ne gidiş̧ir!." (Akyüz, 1959, s. 57).

Milli tarih şuurunu ve mukaddesatını yitiren yabancılaşmış bir zihinde mantık aramak beyhude bir çabadır. Benliğini, kimliğini bir başka medeniyetin değerleriyle tanımlayan bir nesil, bir anlamda haçlı ordu- 
sunun zihniyetine hizmet ediyordur. Fatih' in hesap sorgusunda eylemin faili ve nasıllığı ortadadır ancak Serdengeçti susmaz ve söz konusu dava savunmasına şu sözlerle devam eder. "Savcılık bu davayı yanlış yere getirmiş. Dosyayı Yunanistan'a gönderseydi daha iyi etmiş olurdu. Sanki karşımda, iddia makamında Müslüman bir Türkü değil, Athenagoras'ın mümessilini görüyorum! Ürperiyorum! Ürperiyorum!" (Akyüz, 1959, s. 56).

Serdengeçti, savunmasında yer alan bu ifadeleri ile aynı zamanda Türkiye'nin Batı karşısında boyun eğen bağımlı tutumunu da eleştirmektedir. Batılılaşmayı, Batı medeniyetinin üstünlüğünün kabulünün sonucu olarak gören ve geçmişten kopmayı ilericilik sayan zihniyet karşısında ürperen Serdengeçti, Ayasofya'nın cami olmaktan çıkarılmasını Bat1/Hristiyan emellerine hizmet etmek olarak değerlendirmektedir. Buna mukabil Türkiye'nin iç ve diş işlerinde kelimenin tam ve siyasi anlamıyla bağımsızlığını kazanmasını ise Ayasofya'nın yeniden cami olarak açılmasına bağlı olduğu şeklinde değerlendirdiğini söyleyebiliriz.

Serdengeçti'nin paralelinde Ayasofya'nın müze olarak kalmasında 1srar eden dönemin hükümetini Türkiye'nin bağımsızlığına gölge düşürdüğü savı ile eleştiren isimlerden biri de Mehmet Şevki Eygi'dir. Eygi, 19 Eylül 1962' de Yeni İstiklal dergisinin 92. sayısında “Bu nasıl milli iradedir ki, bir müzeyi cami yaptıramıoor?" (Akyel, 2020,s.141) sorusunu sormuştur.

Osman Yüksel, Serdengeçti dergisinin farklı tarihli yazılarında özellikle dış siyaset alanında Türk dünyası ve Müslüman ülkelerin birlik oluşturması gerektiğini belirtmektedir (Özcan, 2018, s.308). Ayasofya'nın taşımış olduğu mananın idrakine Müslümanlar ancak birlik olarak ulaşabilirler. Zira kendilerini inşa edemeyen insanların mabetler inşa etmesi maddenin zuhurundan başka bir kıymet taşımayacaktır. Ayasofya içerdiği anlam ile Müslümanlar arasında bu köprüyü sağlayacak bir mekândır (Aydeniz, 2020, s.91).

Serdengeçti'nin Ayasofya'ya medeniyet ve fetih nişanesi anlamlarını yüklemesinde vatana, millete koşan, halkı tutan milli tavrı ile Allah'a koşan Hakk'a tapan ${ }^{6}$ inancının etkili olduğu ifade edilebilir. Ayasofya

\footnotetext{
${ }^{6}$ Osman Yüksel'in Türk-İslam medeniyeti anlayışını çıkarttı̆̆ı derginin sloganlarında yansıttı̆̆ını söylemek mümkündür. Serdengeçti dergisinin ilk sayısı "Hakk'a Tapar-Halkı Tutar" sloganı ile çıkmıştır. Derginin kapak sloganları arasında "Allah'a Millete Vatana Koşanların dergisi", "Allah-MilletVatan Yolunda" ve Allah'tan Başka Kimseden Korkmaz" ifadeleri de kullanılmıştır.
} 
yazısında "Ey İslam'ın nuru, Türklüğ̈̈̈n gururu..." sözlerini pekiştiren "Biz Tanrıdağı kadar Türk, Hıradağı (Cebel-i nûr) kadar Müslümanız" (Serdengeçti, 2013, s.30) sözleri Serdengeçti'nin Türk-İslam medeniyetine kuvvetle bağlı olduğunu göstermektedir.

Serdengeçti için Türk demek aynı şuurla İslâm demektir. Ebedi ve ezeli kıymetlerinden uzaklaştırılan, mukaddesatı ayaklar altında çiğnenen bu milletin kaybettiği imanını aradığına, onu isimlere taptırmanın beyhude bir çaba olduğuna, çünkü bu milletin yalnız ve yalnızca Allah'a taptığına, bu milletin putperest olmadığına ancak kendisine hizmet eden şahısları unutmayıp sevip saydığına (Serdengeçti, 1948, s.3-5) dair düşünceleri Ayasofya yazısının dokusunu oluşturmaktadır.

Serdengeçti'nin Türk milliyetçiliği dünyevi ihtiraslar için kullanılan bir araç değildir. Onun için yalınkılıç bir amaç olan milliyetçilik, kâinat nizamına, insan fıtratına en uygun olan, fert ve cemiyet için doğru yolu, kurtuluşu gösteren İslam dinine hizmet içinde değerlendirilmektedir (Böcü, 1997, s.49,79). Bundan sebep Serdengeçti, Ayasofya'ya “...Hani o ilahi devir, ilahi nizamlar?!" diye seslenecek ama İslam'dan ari bir milliyetçiliğin kurbanı olan "Ayasofya ses ver(miyor)"meyecektir.

İslam medeniyetinde cami zamanla etrafında oluşan külliyeyle birlikte İslam'ın hayat kaidelerini temsil eden bir bütün oluşturmakta ve inananların bütün sosyal faaliyetlerini gerçekleştirdiği bir rol üstlenmektedir (And1, 2020c, s.100). Ayasofya camide önemli bir ibadet merkezi olmakla birlikte Osmanlı döneminde siyaset, eğitim, sosyo-kültürel birçok işleve sahiptir. Bu işlevleri yerine getirmesine imkân sağlayacak çeşitli mekânlar Ayasofya'nın çevresine inşa edilmiştir. Ayasofya'ya eklenen medrese, sıbyan mektebi, kütüphane, aşevi, şadırvan, sebiller, muvakkithane, hamam vd. mekânlarıyla sosyal yaşam, nizam kaidelerinin işlerlik kazanması ve sadece Müslümanların değil bütün bir şehir halkının bu hizmetlerden faydalanmasını sağlanmıştır.

Serdengeçti, beşeri hayatın dopdolu aktığı bir zamanların Ayasofya'sına bakıp "Ayasofya bomboş, Ayasofya bir hoş!.." diyerek iç çekecektir. "Ayasofya bomboş" bu iki kelime içine Serdengeçti ızdırabı kadar büyük hakikatleri sığdırmıştır. "Ayasofya bomboş"tur. Çünkü iç mekânda onu o yapan neyi varsa el yazması Kuran ve diğer kitapları, avizeleri, kandilleri, şerefeleri, hat levhaları, halıları...yitiktir. 
"Ayasofya bomboştur". Çünkü dış mekânda onu çevreleyen onunla bir bütün olan kütüphanesi, imarethanesi, mektebi... içleri boşaltılmıştır ve şimdi varlık sebebinden gayrı işlere tahsis edilmiştir. "Ayasofya bir hoştur!". Çünkü kendinden neşet bazı mekânlarını yıkılmaktan koruyamamıştır. Yıkılan bu mekânlardan biri Fatih tarafından yaptırılan ve bir ilim merkezi olan Ayasofya Medresesi'dir. Bu medrese Cumhuriyet döneminde İstanbul Belediyesi tarafından 1924-1935 yılları arasında "Öksüzler Yurdu" olarak kullanılmıştır. Ayasofya'nın çevresini fiziksel olarak ferahlatmak, yapının harap ve perişan olması nedeniyle tarihi eser vasfını kaybettiği gibi söylentiye dayalı gerekçelerle nihayetinde 1936 yılında sebepsiz yere yıkılmıştır (Eyice, 1991b, s.215).

"Ayasofya bomboştur". Çünkü o cemaatini, medresesinde ilim tahsil eden öğrencilerini, sıbyan mektebinde koşturan çocuklarını, aşevinden doyan biçarelerini, sebillerinden su içen kuşlarını kaybetmiştir. Hâlbuki Serdengeçti için Ayasofya insanların nice işler için bir araya gelip buluştukları insana dokunan, insanın dokunduğu bir mekândır.

"Ayasofya bir hoştur!". Çünkü o piyasada bir biletlik değeri olan bir meta olmuştur, onun içinde dolaşan insan güruhu zahirde müze ziyaretçisi özünde bir müşteridir, müşteri ise her zaman haklıdır öyleyse ayakkabılarını çıkartmadan kirli ayakları ile dolaşması da haktır.

Serdengeçti için Selçuklu ve sonrasında kurulan Osmanlı Devleti, büyük bir dünya medeniyetidir (İşler, 2018, s.165). Bu medeniyetin terkedilişinin ardından gelişen Batı medeniyetine öykünme ile İstanbul ve Ayasofya maddeye gark edilmiş sekülerleştirilmiştir.

Serdengeçti, Ayasofya yazısında içinde yaşanılan zamanın sorunlu halini betimlemiştir. "Hani o ilahi devir, ilahi nizamlar" özleminde ve "Kur'an sesleri dindirilmiş, Müslümanlar sindirilmiş" feryadında Ayasofya, mazinin ihtişamı ile şu anki ezilip bükülmüşlüğün, inananların sindirilmişliğin mukayesesini yapan bir mekândır.

Serdengeçti, Ayasofya'nın yazgısını mekânla bütünleştirdiği bireyin alın yazısına nakşeder. Dönemin siyasi kararları neticesinde İslam ruhundan arındırılıp müzeye dönüştürülen Ayasofya'nın yaşadığ 1 mekânsal ve anlamsal yabancılaşma bireylerin yabancılaşmasını da simgelemektedir. Serdengeçti'nin Ayasofya'nın mekânsal ve anlamsal tahribatının tüm Müslümanların benliğinde yaşandığını düşündüğünü söyleyebiliriz. 
Ayasofya ile aynı yazgıyı yaşamak Serdengeçti'de bir aydın sorumluluğu duygusunun açığa çıkmasını ve Ayasofya'nın bir dava haline gelmesini sağlamıştır. Serdengeçti, Ayasofya'ya baktığında ağır bir tahribat altında can çekişen bir mekân görmektedir. "Fethin, Fatih'in mabedinden kitabı mübini, bu ulu dini, kaldıran kim? Dinimize, imanımıza saldıran kim?" cümlelerini şoven bir ruhun hezeyanları olarak değil bir aydın sorumluluğu olarak okumak gerekmektedir.

Serdengeçti, Batı medeniyetinin taklidine ve kültür emperyalizmine karşı aydınların sorumluluğunu hatırlatmaktadır. " Mâzisine, ecdadına, tarihine bağlı her Türk münevverini kültür istismarcılarına, kültür emperyalistlerine karşı mücadeleye davet ediyoruz. ... türlü maskeler, türlü k1lıklar altında memleketimize, milletimizin en mahrem yerlerine kadar girmeye çalışan bu yabancı, yalancı, talancı zevklere, kültür emperyalistlerine karşı mücadele edeceğiz. (Çünkü) Türk Milleti benzeyen bir millet değil benzeten bir millettir. Türk Milleti besleme bir millet değil, besleyen bir millettir." (Serdengeçti, 1958, s.4).

Serdengeçti yazısını, "Ayasofya! Ey muhteşem mabet! Merak etme, Fatihin torunları yakında bütün putları devirip seni camiye çevirecekler. Gözyaşlaryyla abdest alıp secdeye kapanacaklar... Tehlil ve tekbir sadaları boş kubbelerini yeniden dolduracak... Sessiz ve öksüz minarelerinden yükselen tekbir sesleri fezalarn inletecek...Şerefelerin yine Allah'ın ve O'nun sevgili Peygamberi Hz. Muhammed'in şerefine ışıl ışıl yanacak... Bütün dünya Fatih dirildi sanacak. Bu olacak Ayasofya, bu olacak!... Ikinci bir fetih, yeni bir basübadelmevt... bu muhakkak. Bu günler yakın, belki yarın, belki yarından da yakın." sözleri ile müjde vererek bitirmektedir.

Serdengeçti, Ayasofya'da gerçekleşecek ikinci bir fetih, yeni bir basübadelmevt için Allah'ın kudretine sığınmakta, O'nun sevgili peygamberi Hz. Muhammed'in aşkına sarılmakta ve Fatih'in ruhuna yaslanmaktadır.

Serdengeçti'nin kanaatlerini paylaşan Karakoç'ta, inanmış bir millet olarak Ayasofya'yı kendi yüce ismine kavuşturduğumuzda Allah'ın kuvvet ve kudreti ile zafere kavuşturacağından inananların şüphe duymamalarını istemektedir (Karakoç, 1989, s.20).

Serdengeçti'nin müjdesi, İslam medeniyetinin mührünü vurduğu geniş bir coğrafyada yaşayan dindaşların geçmişte olduğu gibi gelecekte de Ayasofya'da secdede buluşacakları günün müjdesini de içermektedir. 
Bu müjde ile Ayasofya yazarın kendi düşünce, inanç ve duygu dünyasının ifadesi iken nesrin sonunda kolektif dirilişin mekânına dönüşür. İstanbul ve Ayasofya her ne kadar yabancılaşma yaşasa da minareleri, kubbeleri ile Doğu-İslam medeniyetinin mahzun mirası olarak ayakta durmakta ve bu medeniyetin tükenmediğini anlatmaktadır. Ayasofya, Müslümanların tarihiyle bağ kurarak yaşadığı keşmekeşten çıkış yolu bulacağı ve geleceği inşa edebilmek için gerekli manevi kuvveti alacağ bir diriliş mekânıdır.

\section{Sonuç}

Medeniyet ve mekân ilişkisinde mekân, medeniyetin varoluş ve etki sahasını belirleyen, medeniyetin görünürlüğünü sağlayan dış sınırlara işaret etmektedir. Bu bağlamda bir medeniyet mekânı olarak değerlendirebileceğimiz Ayasofya, İstanbul'un fethinden günümüze kadar Türk toplumu için merkezi bir öneme sahip olmuştur.

Türkiye'de ulus-devlet formuna geçilmesi ve yeni devletin Osmanlı ile tarihi bağını kesme isteği ile mazinin izlerini taşıyan Ayasofya üzerinde mekânsal ve işlevsel değişikliklere gidilmiştir. Türkiye'nin değişim sürecinde 24 Kasım 1934 tarih ve 7/1589 Bakanlar Kurulu kararı ile Ayasofya'nın müze olma süreci tamamlanmıştır.

Serdengeçti, Ayasofya'da Doğu medeniyetinin mührünü ve İslamTürk kimliğini silme çabaları karşısında derin bir teessür yaşamıştır. Bu derin teessür Serdengeçti'nin çalışmada odak metin olarak seçilen "Ayasofya" ve ilgili diğer yazılarında hissedilmektedir. Ayasofya'ya dair yazılarındaki ortak amaç, Ayasofya'nın bir Bizans müzesi olacak şekilde yapılandırılmasının ardından yeniden cami olmasını böylece mekânda tezahür eden Bizans/Batı Hristiyan medeniyetine ait izleri ve anlamları ters düz ederek mekâna İslam- Türk medeniyeti kimliğini yeniden kazandırmaktır.

Serdengeçti, yolunu Hakk'a sabitlediği için medeniyetin kaynağı vahiydir. İslam, medeniyetin ilkesel yönünü inşa eder. Ayrıca bir toplum, tarihi ve kültürü ile medeniyete eklenerek gelişmesine katkı sağlar. Serdengeçti'nin bu tavrı üst başlık olarak Doğu/İslam medeniyeti kavramsallaştırılmasının yanı başına Türk-İslam medeniyeti kavramının yerleştirilmesine imkân tanımıştır. Serdengeçti için Türk-İslam medeniyeti, 
İslam'ın beynelmilel niteliği ile Türk toplumunun kültürünün milli karakterinin bütünleşmiş bir sentezidir. Serdengeçti'nin dünya görüşü ve kendini ait hissettiği medeniyet anlayışı Ayasofya'ya yüklediği mekânsal anlamı etkilemiştir. Serdengeçti yazısında öncelikle Ayasofya'yı inanç ve mekân ilişkisi içinde ele almaktadır. Ayasofya hikmetin evi olarak içinde rahmet ve huzurun yaşandığı ulu bir mabet, ruhun/mananın maddeye galip geldiği bir vahdet mekânıdır.

Serdengeçti Ayasofya'yı mekân ve birey ilişkisi açısından da ele almaktadır. Ayasofya, coğrafi konumu, kubbeleri, minareleri, şerefeleri ve çevresini saran diğer yapılarla birlikte mevcudiyetini tamamlayan, hem kutsallığa hem de dünyevi hayata hitap eden bir mekândır. Ayasofya, bir mabet olmanın yanı sıra içinde sosyal hayatın cereyan ettiği, insanların dini, etnik, sınıfsal farklılıklarını bertaraf ederek biraya toplandığı, sohbet ettiği, hoşgörünün sel olup önyargı bendini yıktığı bir mekândır. Ayasofya, yardımlaşma ve dayanışma ağları ile insanları birbirlerine bağlamakta, bilgi ve irfanı ışık eyleyip yayarak insanlığa hizmet etmektedir. Bu minvalde Ayasofya bireye mekânla bağı ve aidiyeti çerçevesinde varoluşsal bir kimlik sunmaktadır. Ayasofya, her daim olduğu üzere bugünde insanların tarihsel bilinç düzeylerini biçimlendiren, geçmişiyle geleceğine bağlayan bir süreklilik mekânıdır.

Serdengeçti, yazısında Ayasofya'ya siyasal açıdan da yaklaşmıştır. "Ayasofya" yazısı, Batılılaştırılmak istenen bir toplumun kutsal mabedine siyasal iktidar eliyle yapılmış seküler müdahaleye ve bu müdahalenin gayri meşruluğuna vurgu üzerine oturmuştur. Bu yönüyle Ayasofya, tarihsel köklerinden ve Osmanlı mirasından koparılarak Batılılaşmamodernleşmenin kucağına atılmanın, Batı'ya dâhil olmak için Doğu'dan kalanları kazıyıp atmanın, bağımlı bir bağımsızlığın dramatik bir temsil mekânıdır. Serdengeçti, Batı karşısında Türk-İslam medeniyetinin siyasal mağlubiyeti olarak okuduğu Ayasofya'nın müze olma sürecini ülkenin tam bağımsızlık sorunsalı olarak da değerlendirilmektedir. Allah'a ve O'nun dinine olan tam inançla, Hz. Muhammed'in asırlar öncesinde İstanbul'un fethine dair tüm Müslümanlara verdiği müjdeye ve bu mucizeyi gerçekleştirerek Peygamberin övgüsüne mazhar olan Fatih'in mirasına sahip çımakla bir gün muhakkak yeniden cami olacak Ayasofya'nın minarelerinden okunan ezan sesi ile hakiki özgürlük kazanılacaktir. 
Serdengeçti, Batı medeniyeti karşısında güçten düş(ürül)müş, tarihsel kökenlerinden koparılarak savrulmuş İslam medeniyetinin ve Müslüman Türk toplumunun basübadelmevtini inanç ve tarihsel bilincin kuvvetlendirilmesi ile mümkün olacağını düşünmektedir. Serdengeçti, Ayasofya'yı yalın bir ibadet mekânı olmanın ötesinde konumlandırmakta, Ayasofya ile hemhal olan şahısların (Hz. Muhammed, Fatih Sultan Mehmet ve şehitlerin) geleceğe yönelik misyonlarını hatırlatmaktadır. Böylece Ayasofya, geleceğin inşasında merkezi bir anlam taşıyan, sürekliliğe sahip dinamik bir mekân olarak Serdengeçti'nin davasında müstesna bir yer almıştır.

Serdengeçti, Türk-İslam medeniyetinin ve toplumun gelecekteki kaderini bir anlamda Ayasofya'nın kaderine bağlamaktadır. O, içinde yaşadığ1 ahvalden endişeli ve müteessirdir lakin ne karamsar ne de ümitsizdir. Ayasofya'nın cami olarak açılacağına yürekten inanan Serdengeçti o günü İslam medeniyetinin ve Türk toplumunun diriliş ve kıyam günü olarak resmetmektedir. Serdengeçti, o günü "yaşadıkları ortak acılara, hor görülmelere ve uğradıkları zulmetlere kanlı gözyaşlarıyla ağlayan dindaşlarımızın Ayasofya'da bir araya gelerek Hakk'ın huzurunda secdeye vardıkları bir ittihat günü olarak da muştulamaktadır.

Serdengeçti, yaşadı̆̆ı dönemin Batılılaşma tercihinin, ideolojik kutuplaşmalarının ve siyasal iktidarın baskısı altında Türk-İslam medeniyetine bağlılı̆̆ı ile Ayasofya'yı davasına eklemiş, Türkiye'de tarihe aidiyetin ve İslami aydınlanmanın öncü isimlerinden biri olmuştur. Serdengeçti için Ayasofya'nın hilal hâkimiyetinden koparılması Türk İslam medeniyetinin ruhuna taarruz eden bir felakettir. Bu felaketten selametin yolu Ayasofya'nın hilalle yeniden buluşturulmasıdır ve buna inanan yürekler bir gün mutlaka hilaline kavuşacaktır.

Ĕ̆ger Hilâlimden ayru düşersem

Lanetler olsun bana, onsuz yaşarsam!

Sanmayın ki bir başka yâr bulurum,

İşte o vakitte ben çekilir kaybolurum!

Sis olur, bulut olur, o göklerde dolaşan

Hilâlimi bulurum!...7

\footnotetext{
${ }^{7}$ Osman Yüksel Serdengeçti, Akdeniz Hilâlindir (1936/Antalya) şiirinden alınmıştır.
} 


\section{EXTENDED ABSTRACT}

\section{A Serdengeçti Case on A Scaffold: Hagia Sophia Within the Context of Civilization and Place \\ * \\ Hatice Budak \\ KTO Karatay University}

Place is one of the elements that provides human with realizing itself inside the realm of existence. The relationship between human and place is a relationship system where the subject and object replaced and shaped themselves inside this circular change. Human produced by place, place produced by human and the reproducing process of human by the place, which was produced by human, are the reflections of interaction. Civilization, in this respect, is an accumulation that obtains a unique identity, which emerges from the relationship between place and human, correlates with the symbolic meanings of place and differentiates with this correlation.

Every state and city have a holy place. When it was a Christian land before the conquest and became a Muslim land after conquest, Istanbul's holy place has always been Hagia Sophia. Hagia Sophia is a symbolic place that represents sanctity, worldview, and the culture and history of nation for both Western/Christian and Eastern/Islamic civilizations.

The purpose of this study is to show within the relationship between civilization and place that Hagia Sophia has religious, historical, and cultural meanings for both civilizations, and due to these meanings, it is an area of struggle for both civilizations in line with the analysis of $\mathrm{O}$. Y. Serdengeçti's article, titled "Hagia Sophia".

The method of the study is based on the model consists of three parts as being description, classification and association, which is developed by Dey (1993) and identified "qualitative analysis". Description, which represents the first step of qualitative analysis, is defined as being expressed in writing of basic characteristics regarding person, object and events. After comprehensive description of data, hidden themes rooted in data set is revealed and social reality, which is the subject of investiga- 
tion, is attempted to be explained by correlating these themes (Özdemir, 2010, p. 330-331).

Serdengeçti, whose real name was Osman Ziya Yüksel, had always opposed all kind of developments, which he believed that they were against the history, culture, traditions of Turkish society and the values of Islam.

Serdengeçti, who was violently concerned in terms of national/religious values about welcoming of Greek Patriarch Anthenegaros on his visit in Turkey in 1952 as if he was a state/government official and publications of Greek press and activities of Greeks in Turkey for reconstructing Hagia Sophia as Church faithfully, wrote an article, titled Hagia Sophia". The article had been published in $17^{\text {th }}$ issue of Serdengeçti Journal, August-1952 Volume.

Serdengeçti felt a deep sadness due to attempts of erasing the seal of Eastern Civilization and Turkish-Islamic identity in Hagia Sophia after the completion of the process of being a museum of the structure by the Cabinet Decision, articled 7/1589 signed on 24 November 1934. This deep sadness can be felt in "Hagia Sophia", which is the focus text and the other writings. The common purpose on the writings about Hagia Sophia is to see this structure again as Mosque after being structured as Byzantium museum, so re-bringing the place in the identity of IslamicTurkish civilization by turning inside out the traces and meanings belong to Byzantium/Western civilization.

Serdengeçti's worldview and the understanding of civilization in which he felt belonging had affected the spatial meaning he felt through Hagia Sophia. In his article, Serdengeçti initially approaches Hagia Sophia within the relationship between belief and place. Hagia Sophia is a unity place where the spirit/meaning prevails the material and a paramount temple in which mercy and tranquillity is experienced as the house of wisdom.

Serdengeçti also deals with Hagia Sophia from the perspective of the relationship between place and individual. Besides being a temple, Hagia Sophia is a place where social life is maintained, people come together and have talks by eliminating all of the differences regarding religious, ethnic and class, and tolerance floods and breaks down the prejudice dam inside. As it has always been, today Hagia Sophia is a continui- 
ty place that shape people's historical level of consciousness and ties humanity with the future thanks to its past.

Serdengeçti also approaches Hagia Sophia in terms of political aspect in his article. The writing of "Hagia Sophia" is based on the emphasis about a secular intervention on the holy temple of a society, which is attempted to be Westernized, and the illegality of this intervention. In this respect, Serdengeçti evaluates the process of Hagia Sophia becoming a museum, which he reads as the political defeat of the Turkish-Islamic civilization against the West, as a problematic of the country's total independence.

Serdengeçti was concerned and influenced due to situation he experienced; however, he was neither pessimistic nor hopeless. Serdengeçti, who believed wholeheartedly the opening of Hagia Sophia as Mosque, finalized his article with the evangel of that day would definitely come.

By this evangel, when Hagia Sophia was the expression of writer's own thought, belief and emotional world, it becomes the place of collective resurrection at the end of the text. Although Istanbul and Hagia Sophia experienced alienation, it stands as the gloomy legacy of Eastern/Islamic civilization and expresses that this civilization has never ended. Hagia Sophia is a resurrection place, in which Muslims will find a way out from the disorder by connecting with their past and take the necessary moral power to construct the future.

\section{Kaynakça / References}

Akan, E. (2008). Cumhuriyet döneminde Ayasofya. Yayınlanmamış yüksek lisans tezi, Çanakkale On Sekiz Mart Üniversitesi, Çanakkale.

Akçay, İ. (1967). Harbi Umumi'de Ayasofya. Hakses Mecmuası, 4(43), 5-6.

Akçay, İ. (1999). Ayasofya camii. Ankara: Hakses Yayınları.

Akgündüz, A., Öztürk, S., ve Baş, Y. (1994). Kiliseden müzeye Ayasofya camii. İstanbul: Osmanlı Araştırmaları Vakfı Yay.

Akgündüz, A., Öztürk, S., ve Baş, Y. (2005). Üç devirde bir mabed Ayasofya. İstanbul: Osmanlı Araştırmaları Vakfı Yay.

Akyel, S. (2020). Mehmet Şevket Eygi ve Ayasofya mücadelesi. Ayasofya Dergisi, Şükür Sayısı, 138-143. 
Akyüz, M. E. (1959). Ayasofya davası Ayasofya'nın hakiki ve hukukî durumu. İstanbul: Derin Tarih Kültür Yayınları.

Andı, M. F. (2020a). Ayasofya müşahedeleri. Üsküdar Kültür, Sanat ve Medeniyet Dergisi, 10, 8-11.

Andı, M. F.(2020b). “Biraz daha rahmet yağsın”: Sel, yaratıcı yıkım ve Ayasofya. Üsküdar Kültür, Sanat ve Medeniyet Dergisi, 10, 18-25.

Andı, M. F. (2020c). Dokuz Ayasofya'nın en büyüğ̈ü. Ayasofya Dergisi, Şükür Sayısı, 98-101.

Aslan, F. (2009). Ayasofya efsaneleri. Yayınlanmamış doktora tezi, İstanbul Üniversitesi, İstanbul.

Aydeniz, Y. B. (2020). Anlam tasavvuru ve toplumsal inşâ arasında Ayasofya. Ayasofya Dergisi, Şükür Sayısı, 90-91.

Balcıoğlu, A. (1991). Osman Yüksel Serdengeçti. İstanbul: Timaş Yayınları.

Bardakçı, İ. (2006). Imparatorluğun yă̆ması. İstanbul: Türk Edebiyat Vakfı Yay.

Başaran, A. E. (2020). Hasretten vuslata bir Ayasofya rüyası. Ayasofya Dergisi, Şükür Sayısı, 48-49.

Böcü, S. (1997). Osman Yüksel Serdengeçti, hayatı, edebi şahsiyeti, fikirleri, eserleri.Yayınlanmamış yüksek lisans tezi, Selçuk Üniversitesi, Konya.

Braudel, F. (2017). Uygarlıkların grameri (M. A. Kılıçbay, Çev.). Ankara: İmge Kitapevi Yayıncılık.

Cansever, T. (2010). İslâm'da şehir ve mimari.İstanbul: Timaş Yayınları.

Çebi, H. Y. (2006). Judasofyal Aya Sofya ve Patrikhane üzerinde oynanan gizli oyunlar.İstanbul: Pegasus Yayınları.

Dukas, M. (1956).Bizans tarihi (V. Mirmiroğlu, Çev.). İstanbul: İstanbul'un Fethi Derneği.

Dursun, A. H. (2020). Bir ulu mabetten şehri okumak. Üsküdar Kültür, Sanat ve Medeniyet Dergisi, 10, 43-47.

Enser, R. (2018). Sezai Karakoç'un şiirlerinde geleneğin tezahür odakları olarak insan, zaman ve mekân.Yayınlanmamış doktora tezi, Fatih Sultan Mehmet Vakıf Üniversitesi, İstanbul.

Eyice, S. (1984). Ayasofya 1. İstanbul: Yapı Kredi Bankası Kültür Yay.

Eyice, S. (1986). Ayasofya 3. İstanbul: Yapı Kredi Bankası Kültür Yay.

Eyice, S. (1991a). Ayasofya. Türkiye Diyanet Vakfi İslam ansiklopedisi içinde. (Cilt. 4, s. 206-210). İstanbul: Türkiye Diyanet Vakfı Yayınları.

Eyice, S. (1991b). Ayasofya medresesi. Türkiye Diyanet Vakfı Íslam ansiklopedisi içinde. (Cilt. 4, s.214-215). İstanbul: Türkiye Diyanet Vakfı Yayınları. 
Eyice, S. (1993). Ayasofya. Osmanl ansiklopedisi içinde.(Cilt. II, s.44-49). İstanbul: Ağaç Yayıncilık.

Görmez, M. (2020). İslam medeniyetinde mabet hukuku ve Ayasofya. Ayasofya Dergisi, Şükür Sayısl, 23-29.

Güney, E. (2020). İstanbul kent imgesi olarak Ayasofya. Yayınlanmamış yüksek lisans tezi, Marmara Üniversitesi, İstanbul.

İkinci, A. (2014). Osmanlı'dan Cumhuriyet'e Ayasofya.Yayınlanmamış yüksek lisans tezi, Atatürk Üniversitesi, Erzurum.

İşler, A. (2018). Osman Yüksel Serdengeçti'nin muhalefet anlayışı. Tarih ve Gelecek Dergisi, 4(3), 162-180.

Jaeschke, G. (1991). Kurtuluş savaşı ile ilgili İngiliz belgeleri (C. Köprülü, Çev.). Ankara: Türk Tarih Kurumu Yayınları.

Kalın, İ. (2010). Dünya görüşü, varlık tasavvuru ve düzen fikri: Medeniyet kavramına giriş. Dîvân: Disiplinlerarası Çalışmalar Dergisi, 29, 1-61.

Kandemir, İ. (2005). Ulu mabed Ayasofya. İstanbul: Ekip Matbaası.

Karaçam, F. (2009). Serdengeçti, Osman Yüksel. Türk Diyanet Vakfı İslam Ansiklopedisiiçinde.(C.36, s.555-556). İstanbul: Türkiye Diyanet Vakfı Yayınları.

Karakoç, S. (1989). Günlük yazılar II sütun. İstanbul: Diriliş Yayınları.

Karakoç, S. (1990). Kaderimizin Ayasofya'sı, Ayasofya'mızın kaderi. Diriliş Dergisi, 7(78), 2-13-14.

Karakoç, S. (2005). Düşünceler I-Kavramlar.İstanbul: Diriliş Yayınları.

Karakoç, S. (2012). Çıkış Yolu II medeniyetimizin dirilişi. İstanbul: Diriliş Yayınları.

Kazıcı, Z. (2009). İslam medeniyeti ve müesseseleri tarihi. İstanbul: M.Ü. İlahiyat Fakültesi Vakfı Yayınları.

Kısakürek, N. F. (2016). Hitabeler.İstanbul: Büyük Doğu Yayınları.

Kleinbauer,W. E.,A.Whitte, A., veMatthews, H. (2004). Ayasofya (H. Cingi, Çev.). İstanbul: Arkeoloji ve Sanat Yay.

Lefebvre, H. (2014). Mekânın üretimi (I. Ergüden, Çev.). İstanbul: Sel Yayınc1lik.

Mansel, A. M. (1979). Ayasofya. Milli Ĕğitim Bakanlı̆̆ı İslam ansiklopedisi içinde.(Cilt II, s.47-55). İstanbul: İstanbul Maarif Matbaası.

Meriç, C. (2004). Jurnal cilt 2. İstanbul: İletişim Yay.

Müftüoğlu, M. (1988). Cumhuriyet devrinde mühim olaylar. İstanbul: Seha Neşriyat. 
Mülayim, S. (2002). Kubbe. Türkiye Diyanet Vakfi İslam ansiklopedisi içinde. (Cilt. 26, s. 300-303). İstanbul: Türkiye Diyanet Vakfı Yayınları.

Niyazi, M. (20007). Türk devlet felsefesi. İstanbul: Ötüken Yayınları.

Oktay, C. (2012). Siyaset bilimi incelemeleri. İstanbul: Alfa Yayınları.

Özcan, A. (2018). Tek kişilik kültür ve medeniyet ordusu: Serdengeçti dergisi. L. Sunar (Ed.).Isslam'ı uyandırmak çok partili yaşama geçilirken İslamcı düşünce ve dergiler içinde (s. 289-318), İstanbul: İLEM.

Özdemir, M. (2010). Nitel veri analizi: Sosyal bilimlerde yöntembilim sorunsalı üzerine bir çalışma. Eskişehir Osman Gazi Üniversitesi Sosyal Bilimler Dergisi, 11(1), 323-343.

Özkul, O. (2004). Şemseddin Sami'ye göre Batı medeniyeti ve İslam medeniyeti. Sosyoloji Konferansları, 29,163-174.

Öztoprak, N. (2020). Ayasofya'nın hatırlattığı gelenek: Fetih ve hutbe. Üsküdar Kültür, Sanat ve Medeniyet Dergisi, 10,27-31.

Öztürk, N. (1995). Türk yenileşme tarihi çerçevesinde vakıf müessesesi.Ankara: Türkiye Diyanet Vakf1 Yayınları.

Öztürk, S. (2003). İstanbul'un fethinden sonra Ayasofya kilisesinin camiye çevrilişi. Selçuk Üniversitesi Türkiyat Araştırmaları Dergisi, 14, 133142.

Safa, P. (1990). Din, inkılâp, irtica. İstanbul: Ötüken Yayınları.

Salman, C. (2015), Didem Madak şiirinde zaman ve mekân. S. Zelyut (Haz.).Didem Madak"ı okumak içinde(s.217-250). İstanbul: Metis Yayınları.

Serdengeçti, Osman Yüksel (1948). Nereye Gidiyoruz. Serdengeçti Dergisi, 1(4), 3-5.

Serdengeçti, Osman Yüksel (1952a). Ayasofya. Serdengeçti Dergisi, 6(17), 3.

Serdengeçti Dergisi (1952b). Fatih Sultan Mehmet Han'ın hitabı. 6(15-16), 34.

Serdengeçti, Osman Yüksel (1956). Ayasofya. Serdengeçti Dergisi, 10(22), 5-7.

Serdengeçti, Osman Yüksel (1958). İş başına: Davet. Serdengeçti Dergisi, 11(27), 3-4.

Serdengeçti, Osman Yüksel (1959). Fatih uyanıyor Fatih Sultan Mehmet'in hitab1. Serdengeçti Dergisi, 11(30), 2-4.

Serdengeçti, Osman Yüksel (2013). Mabetsiz şehir-bu millet neden ağlar. İstanbul: Türk Edebiyat Vakfı Yayınları. 
Şemşek, V. (2020). İslam medeniyetinin temelleri ve tarihi gelişim süreçleri.

Karadeniz Uluslararası Bilimsel Dergi, 1(45), 280-290. doi: 10.17498/kdeniz.674435

Thorns, D. C. (2004). Kentlerin dönüşümü kent teorisi ve kentsel yaşam (E. Nal, Çev.). İstanbul: Soyak Yayınları.

Türk Dil Kurumu (2009). Türkçe sözlük. Ankara: Türk Dil Kurumu Yayınlar1.

Yakın Tarih Ansiklopedisi (1989). Cilt. VII. İstanbul: Yeni Nesil Yay.

17.11.2020 tarihinde https:/www.memurlar.net/haber/915648/danistay-inayasofya-karari-gerekcesi-aciklandi.htmladresinden erişildi.

17.11.2020 tarihinde https://www.akparti.org.tr/media/324424/agustos_2020.pdf_adresinden erişildi.

17.11.2020 tarihinde http://www.agos.com.tr/tr/yazi/2769/dostoyevskihayallerinde-ayasofyayi-yeniden-haclandirmisadresinden erişildi.

17.11.2020 tarihinde https://pace.coe.int/en/files/9628 adresinden erişildi.

17.11.2020 tarihinde https://www.dunya.com/gundem/ayasofya-ile-ilgilidunyadan-ilk-tepkiler-haberi-474885adresinden erişildi.

17.11.2020 tarihinde https://haberglobal.com.tr/dunya/ayasofya-kararinadunyada-kimler-destek-verdi-57659adresinden erişildi.

\section{Kaynakça Bilgisi / Citation Information}

Budak, H. (2021). Darağacında bir serdengeçti davası: medeniyet ve mekân bağlamında Ayasofya. OPUS-Uluslararası Toplum Araştırmaları Dergisi, 18(39), 856-894. DOI: 10.26466/opus.850459 